\title{
Assessment and Mitigation of Streamflow and Sediment Yield under Climate Change Conditions in Diyala River Basin, Iraq
}

\author{
Mahmoud S. Al-Khafaji ${ }^{1, *(1)}$ and Rana D. Al-Chalabi ${ }^{2}$ \\ 1 Civil Engineering Department, University of Technology, Baghdad 3242, Iraq \\ 2 Engineering Study and Design Center, Ministry of Water Resources, Baghdad 3253, Iraq \\ * Correspondence: 41100@uotechnology.edu.iq; Tel.: +9647801618485
}

Received: 8 June 2019; Accepted: 19 July 2019; Published: 23 July 2019

\begin{abstract}
The impact of climate change on the streamflow and sediment yield in the Derbendkhan and Hemrin Watersheds is an important challenge facing the water resources of the Diyala River in Iraq. The Soil and Water Assessment Tool (SWAT) was used to project this impact on streamflow and sediment yield until year 2050 by applying five climate models for scenario A1B involving medium emissions. The models were calibrated and validated based on daily observed streamflow and sediment recorded for the periods from 1984 to 2013 and 1984 to 1985, respectively. The Nash-Sutcliffe efficiency and coefficient of determination values for the calibration (validation) were $0.61(0.53)$ and 0.6 (0.62) for Derbendkhan and Hemrin, respectively. In addition, the average of the future predictions for the five climate models indicated that the streamflow (sediment yield) for the Derbendkhan and Hemrin Watersheds would decrease to $49 \%(43.7 \%$ ) and $20 \%$ (30\%), respectively, until 2050, compared with the observed flow of the base period from 1984 to 2013 . The spatial analysis showed that $10.4 \%$ and $68 \%$ of the streamflow comes from Iraqi parts of the Derbendkhan and Hemrin Watersheds, respectively, while $10 \%$ and $60 \%$ of the sediment comes from the Iraqi parts of the Derbendkhan and Hemrin Watersheds, respectively. Deforestation of the northern part of the Hemrin Watershed is the best method to decrease the amount of sediment entering the Hemrin Reservoir.
\end{abstract}

Keywords: Diyala River; SWAT model; climate change

\section{Introduction}

Under natural conditions, climate patterns can change following a specific trend. During the last century, a rapid change in this pattern occurred due to an increase in the surface air temperature and a decrease in precipitation. Natural and human-made factors are the essential causes of this rapid change [1].

Climate change is reflected in the characteristics of watershed hydrology, such as streamflow and sediment yield, and can manifest as a long period of drought followed by extensive flooding over a short time period [2]. In the upper Tigris River in Turkey, precipitation will decrease under the impact of climate change to $12.5 \%$ by 2021 and $26 \%$ by 2030 [3]. In addition, the runoff will decrease to $30 \%$ after 2040. In recent decades, Iraq has experienced serious problems in its water resource sector, including water resource reductions, pollution, and desertification [4]. Iraq is located in a semiarid region of the Middle East, and during the last few decades it has faced extreme climate events. For example, a severe drought from 2007 to 2009 was followed by extreme rainfall that occurred over the course of a few months in southern parts of Iraq, with approximately two times the normal amount [5]. A geographic information system (GIS) was used to assess the impact of climate change in Iraq and Jordan [6]. This study indicated that the climate will be drier, natural land cover will be 
poorer, water resources will decrease, and temperatures will be higher. The Diyala River is one of the most important tributaries of the Tigris River, but its water resources suffer from scarcity and an increase in the sediment rate. The main purposes of water use in the Diyala River are agricultural, drinking, and industrial. In the Tigris River Basin and the Diyala River, water resource deterioration is indicated, and severe shortages in all water resources are expected, especially in the streamflow, for the future $[7,8]$. However, a comprehensive understanding of the impact of climate change on the water resources of the Diyala River is needed [9]. Considering the rapid decrease in the Dokan Dam's reservoir capacity (near the Derbendkhan Reservoir), it was concluded that the sediment is the main problem facing this reservoir [10]. An investigation of the negative effects of sedimentation in the Mosul Dam's reservoir showed that sediment plays an important role in the reservoir capacity and usually blocks the intakes of the pump stations [11]. The spatial and temporal distributions of streamflow and sediment yield depend on characteristics of rainfall such as the intensity and duration, topography, land cover, and soil type of the watershed [12]. A lack of effective land cover to catch the surface soil allows surface runoff to erode the surface soil, which is considered to be an unacceptable phenomenon for reservoir operation. Land cover management is a traditional method to reduce the sediment yield of a watershed [13].

The Soil and Water Assessment Tool (SWAT) is a semidistributed, physically-based hydrological model developed by the United States Department of Agricultural (USDA) Agricultural Research Service (ARS). The model was developed essentially to evaluate the impact of watershed management practices on surface runoff, sediment, and chemical yields in large and complex hydrologic systems [14]. SWAT efficiently simulates and quantifies the water quantity and quality in watersheds under various topographic, land management, and soil conditions and simulates hydrologic components under different climates and land practices [15]. Alwan et al. (2018) [16] showed that the digital elevation model (DEM) resolution is most effective on simulated streamflow. SWAT can be used to analyze water resource management strategies [17]. In addition, Leta and Chakravarti (2017) [18] showed that deforestation reduces surface runoff and soil erosion. Principe (2012) [19], Li and Gao (2015) [20] and Zhou et al. (2017) [21] show that the weather data referring to climate change is important for controlling the sediment yield over a watershed. However, Al-Khafaji et al. (2017) [22] concluded that, with the best calibrated parameters, a SWAT suspended sediment load estimation model could be effectively used for long-term streamflow modeling within the Al-Adhaim Watershed in Iraq. Moreover, using the SWAT model, Alwan et al. (2018) [23] predicted that the sediment depth in the Wadi Al-Naft Watershed in eastern Iraq for the period from 2010 to 2020 would be $1.7 \mathrm{~mm}$; also, the study showed that SWAT is sensitive to the number of sub-basins in the watershed. Moreover, Sehgal et al. ((2018) [24] highlighted the strong correlation between climate indices and watershed-scale hydrologic variables and provided important insights into the effect of seasonality and the dynamics of water balance components on the predictability of drought at the watershed scale.

Subsequently, Al-Khafaji and Saeed (2018) [25] illustrated that fine-resolution input data in a SWAT model do not necessarily improve the accuracy of the modeling results. Abbas et al. (2018) [26] investigated the impact of climate change on Iraq. Firstly, the study investigated the capabilities of five hydrologic models: SWAT, CREAMS, WEPP, AGNPS, and EUROSEM. SWAT was the model selected for its high capabilities in water resource and climate change modeling. Climate Forecast System Reanalysis (CFSR) data can be more reliably used in SWAT models in ungauged watersheds or watersheds of poor gauging [27]. For calibration and validation of a SWAT model, a good simulation can be obtained if the Nash-Sutcliffe efficiency (NSE) is greater than 0.75, while the simulation is satisfactory if the NSE is greater than 0.5 [28]. Fuka et al. (2013) [29] recommended using CFSR in SWAT for streamflow simulations. Currently, the Intergovernmental Panel on Climate Change (IPCC) provides general circulation models (GCMs) to predict monthly precipitation and surface air temperatures, which can be projected by the sediment and streamflow using the SWAT model. 
As no study has addressed the impact of climate change on the temporal and spatial distribution of the streamflow and sediment yield of the Diyala River, in this study, SWAT was used to compute the temporal and spatial distribution of streamflow and sediment yield and the potential future impact of climate change on the streamflow and sediment yield in the Diyala River Basin, Iraq. This should help to develop a deep understanding of the Diyala River's water resources to plan and design future projects. Moreover, conventional sediment mitigation has been applied to parts of most sediment-producing sub-basins. To this end, the SWAT model was implemented in a daily time step using the required spatial and temporal input data.

\section{Methods and Materials}

\subsection{Methodology}

In this study, the streamflow and sediment yield were simulated for the Diyala River using the SWAT model. Firstly, the model was run for the base period from 1984 to 2013. For this period, the streamflow and sediment yield were assessed and the spatial distributions of these hydrologic components were analyzed for both the Derbendkhan and Hemrin Watersheds (the main watersheds of the Diyala River). Also, the past climate precipitation and surface air temperature were projected into future climate until 2050 based on scenario A1B using five climate models: gfdl_cm2_1.1, bccr_bcm2_0.1, cnrm_cm3.1, giss_model_e_r.1, and mri_cgcm2_3_2a.1. The results of the future streamflow and sediment yield were evaluated to show the impact of climate change on the water resources of the Diyala River. Moreover, some conventional sediment mitigation methods were modeled for the Iraqi part of the Hemrin Watershed; then, the streamflow and sediment yield of this watershed were evaluated.

\subsection{Study Area}

The Diyala River Basin is located in a semiarid region of the Middle East between latitudes $44.500^{\circ} \mathrm{E}$ and $46.833^{\circ} \mathrm{E}$ and longitudes $33.216^{\circ} \mathrm{N}$ and $35.833^{\circ} \mathrm{N}$. The watershed is divided between Iraq and Iran and has a total area of $32,600 \mathrm{~km}^{2}, \sim 41 \%$ of which is in Iraq and the remainder in Iran. The Diyala River originates in the Zagros Mountains inside Iran and has three main tributaries: the Sirwan, Tanjeru, and Wand Rivers [30]. The river flows from east to west and then joins the Tigris River $\sim 5 \mathrm{~km}$ south of Baghdad City, with a total length of $445 \mathrm{~km}$ [7]. The river is divided into three parts: the upper part is located between the Zagros Mountains and Derbendkhan Dam, the middle part is located between the Derbendkhan and Hemrin Dams, and the lower part is between the Hemrin Dam and the Tigris River, as shown in Figure 1. Several small dams were built across small streams in the Iranian part of the watershed for harvesting purposes; also, two large dams and one barrage were constructed inside the Iraqi part of the watershed:

Derbendkhan Dam: An earth dam constructed in the upper part of the Diyala River in 1961 approximately $230 \mathrm{~km}$ northeast of Baghdad for multiple purposes, such as protecting Baguba and Baghdad from floods, irrigation, and hydropower generation. It covers $16,750 \mathrm{~km}^{2}, 20 \%$ of which is in Iraq and the remainder is in Iran. The total storage capacity of the Derbendkhan Reservoir is 3 billion cubic meters (BCM).

Hemrin Dam: An earth dam constructed in the middle part of the Diyala River in 1981, about $120 \mathrm{~km}$ east of Bagdad for the purposes of hydropower generation and irrigation, as part of the Khalus Irrigation Project. The total area of the Hemrin Dam Watershed is $12,822 \mathrm{~km}^{2}, 68 \%$ of which is inside Iraq and the remainder is in Iran. The total capacity of the Hemrin Reservoir is $2.4 \mathrm{BCM}$.

Diyala Barrage: A 44 redial gate barrage constructed in 1966 to regulate the water flow for the Khalus and Sudor Irrigation Projects. The barrage is located downstream of the Hemrin Dam by $11 \mathrm{~km}$, $\sim 130 \mathrm{~km}$ northeast of Baghdad [31]. Table 1 shows details of the topographic characteristics of the Derbendkhan and Hemrin Watersheds. 


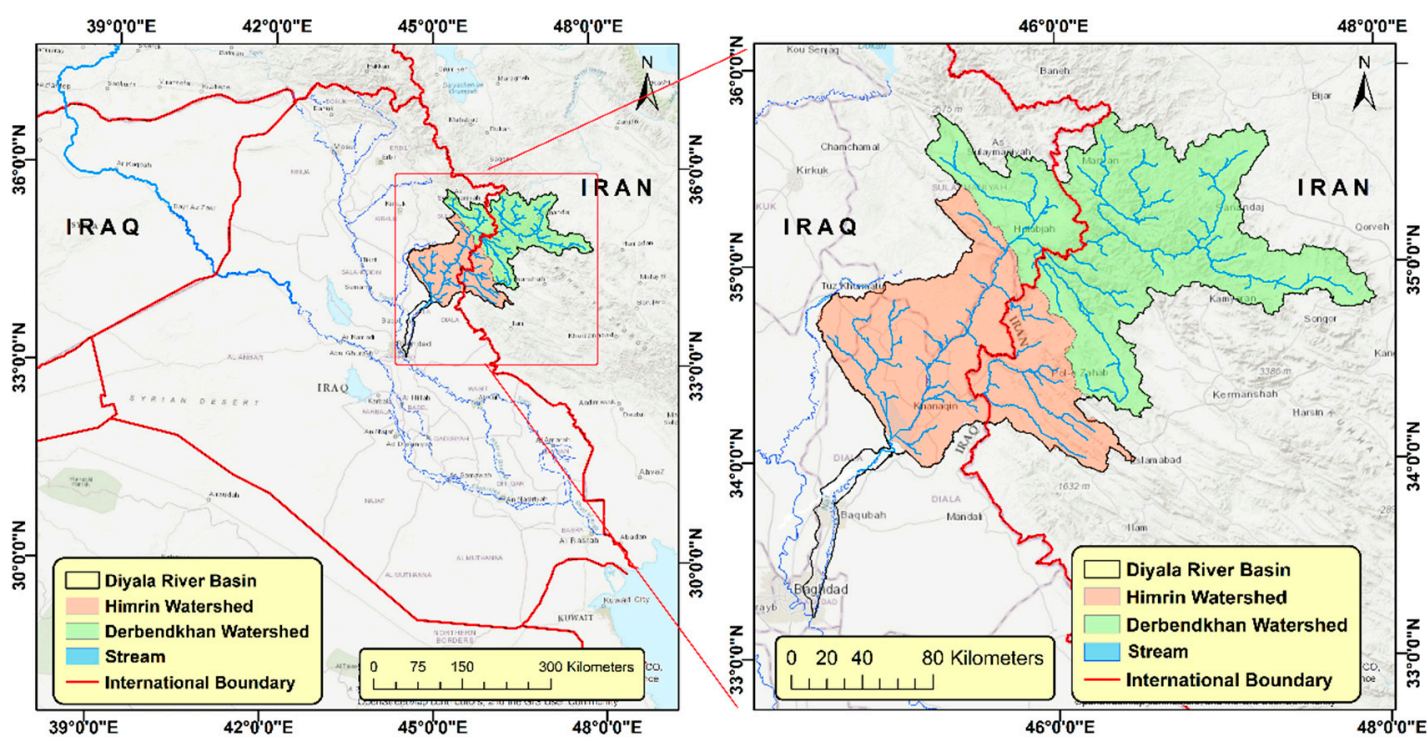

Figure 1. Map of the Diyala River Basin.

Table 1. Topographic characteristics of the Derbendkhan and Hemrin Watersheds.

\begin{tabular}{ccc}
\hline Topographic Character & Derbendkhan & Hemrin \\
\hline Total area km ${ }^{2}$ & 16,750 & 12,822 \\
Percentage of Iraqi Part (\%) & 20 & 68 \\
Percentage of Iranian Part (\%) & 80 & 32 \\
Minimum ground elevation (m.a.s.l) & 376 & 86 \\
Maximum ground elevation (m.a.s.l) & 3345 & 2556 \\
Mean ground elevation (m.a.s.l) & 1574 & 533 \\
Minimum slope & 0 & 0 \\
Maximum slope & 319 & 217 \\
Mean slope & 25.7 & 9.28 \\
\hline
\end{tabular}

\subsection{Input Data}

The input data applied in the SWAT model for successful simulation were DEMs, land cover digital maps, soil, and weather data. The datasets suggested Al-Khafaji and Saeed (2018) [25] were utilized in this study, including the Shuttle Radar Topographic Mission (SRTM), which is a collaborative mission by the National Aeronautics and Space Administration (NASA); the Italian and German space agencies; and the National Geospatial-Intelligence Agency (NGA). The SRTM provides DEM datasets for all global surfaces with approximately $90 \times 90 \mathrm{~m}$ of spatial resolution (Figure 2). The Moderate-Resolution Imaging Spectroradiometer (MODIS) provides global land cover and land use for a yearly time step with $500 \times 500 \mathrm{~m}$ of spatial resolution (Figure 3). MODIS land cover data are produced based on a supervised classification algorithm using high-accuracy training points of high-resolution images for a global conjunct with an ancillary dataset [32]. The Food and Agricultural Organization (FAO) of the United Nations (UN) produced a digital soil dataset for the entire world at 1:500,000 in vector scale (Figure 4). The CFSR contains global weather data produced by the National Weather Service (NWS) and the National Centers for Environmental Prediction NCEP of the Global Forecast System. The forecast model reanalysis occurs every $6 \mathrm{~h}$ using observed weather data from international ground station networks and satellite extractions. CFSR regenerates a global grid of weather stations in $38 \times 38 \mathrm{~km}$ of spatial resolution [29]. The weather generators of CFSR were added to the SWAT weather database. The weather data required by SWAT were defined in the SWAT weather window, including maximum and minimum temperatures, precipitation, solar, relative humidity, and wind speed. The CFSR dataset was used after assessing it in comparison with available monthly gauged 
precipitation data that were recorded at the Khaneqen Gauge Station from January 1984 to December 2002 (unpublished data).

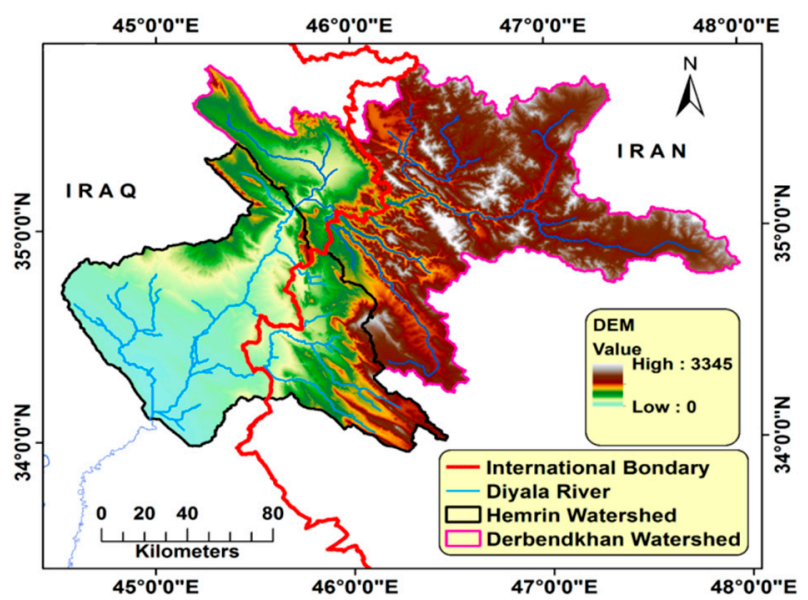

Figure 2. Shuttle Radar Topographic Mission (SRTM) digital elevation model (DEM) $(90 \times 90 \mathrm{~m}$ spatial resolution).

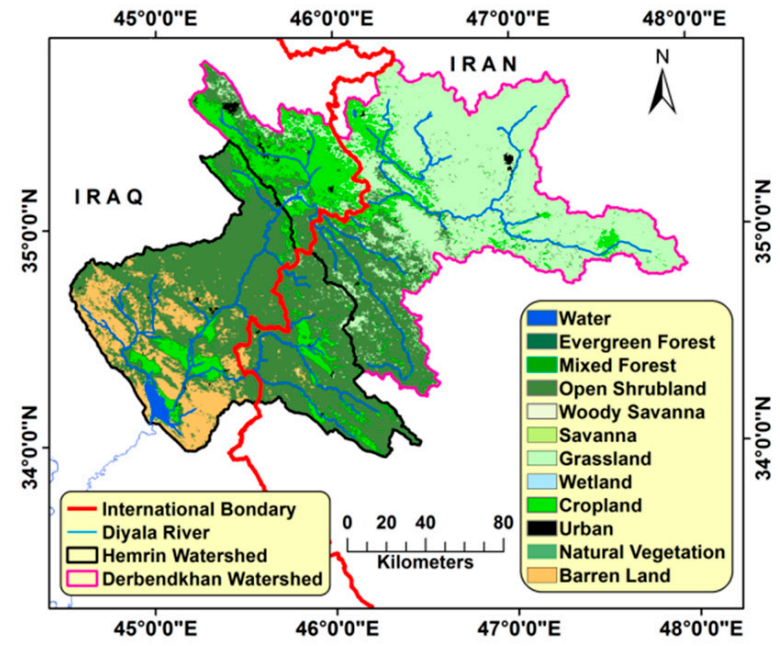

Figure 3. Moderate-Resolution Imaging Spectroradiometer (MODIS) land cover $(500 \times 500) \mathrm{m}$ spatial resolution.

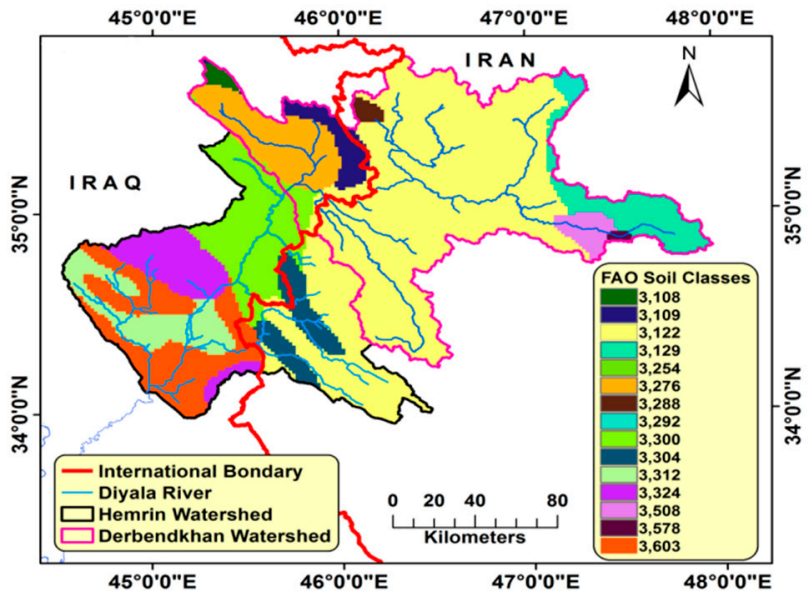

Figure 4. FAO soil data applied into SWAT. 
The observed streamflow recorded in the Diyala River Basin was provided by the Iraqi Ministry of Water Resources MoWR for the period from 1 January 1984 to 31 December 2013 in a daily time step (MoWR, 2018, unpublished data), and the observed daily sediment loads deposited in the Hemrin Reservoir for the period from 1 June 1984 to 31 May 1985 was taken from [33].

Five GCMs of global climate-gfdl_cm2_1.1, bccr_bcm2_0.1, cnrm_cm3.1, giss_model_e_r.1, and mri_cgcm2_3_2a.1-were used for the Diyala River Basin for future climate projection to 2050 based on the A1B scenario of medium emissions. These are the most popular GCMs and cover all scenarios of future climate change [34].

The future monthly based changes in the precipitation and surface air temperate were processed and redefined to the calibrated SWAT model. The climate change data were downloaded from the climate wizard website of the Nature Conservancy of the Universities of Washington and Southern Mississippi.

All the spatial input data were projected to the UTM_Zone_38_N coordinate system then applied to the SWAT model.

\subsection{Setting the SWAT Model}

The downloaded digital dataset (in 2018) (DEM, land cover and land use (LCLU), soil, and weather data) were processed using the ESRI ArcGIS 10.3 program connected with Arc SWAT 2012, which were used for all spatiotemporal processing, such as clipping, projection, transfer from vector to raster, and temporal simulation of streamflow and sediment. The DEM-based method of the SWAT model was used in watershed delineation and streamflow definition. In addition, land cover, soil, and slope data were used to generate the hydrologic response units (HRUs), and the classifications of land cover and soil addressed by MODIS and FAO were applied in the SWAT to connect these data with the SWAT database. In order to cover all variations of watershed slope, the slopes were classified into four classes: $0-10,10-20,20-30$, and $>30$, according to slopes calculated by the DEM-based method implemented in SWAT. All datasets were considered with zero approximation suggested by SWAT. The SWAT model was run for a period of 30 years, from 1 January 1984 to 31 December 2013, in a daily time step. Moreover, the streamflow and sediment yield for this period were extracted and the spatial distributions of streamflow and sediment source were presented according to the streamflow and sediment yield of each sub-basin.

\subsection{Calibration, Validation, and Sensitivity Analysis}

In order to obtain a reasonable simulation using the SWAT hydrologic model, it was necessary to calibrate and validate the simulation against observations. The SWAT Calibration and Uncertainty Program (CUP) is an automatic mathematic calibration that includes five program procedures linked to SWAT with an optional objective function of optimization. In this study, the sequential uncertainty fitting (SUFI-2) algorithm was used in SWAT-CUP for calibration and validation processes; also, a global sensitivity analysis with $t$-tests and $p$-values was used to assess the sensitive parameters. The NSE [35] was set as the objective function in SWAT-CUP to allow the SUFI-2 program to optimize the best correlation between simulations and observations. In addition, SWAT-CUP provided two statistical indicators of correlation: the P-factor, which is the percentage of observed data enveloped by the range of simulations generated by the range of hydrologic parameters used in calibration, and the R-factor, which is the thickness of the 95\% prediction uncertainty (95PPU) envelope.

The initial results of SWAT were copied into SWAT-CUP. Then, all necessary formatting of observations and periods of calibration and validation were set in SWAT-CUP. For the Derbendkhan Watershed, the observed surface streamflow from 1 January 1984 to 31 December 2004 was used in calibration and from 1 January 2005 to 31 December 2013 was used in validation. Due to the unavailability of observed sediment in the Derbendkhan Watershed, the best result of the calibrated streamflow was considered as a reasonable simulation of the sediment loads deposited in the Derbendkhan Reservoir. The same procedures and period of calibration and validation were used for 
the Hemrin model, except for using the observed sediment in calibration for the period from 1 June 1984 to 31 May 1985.

The parameter regionalization was done based on the sensitivity analysis of different parameter sets and the suggested parameters in [36,37]. For both watersheds, SWAT-CUP was set in 300 simulations in the first iteration of calibration for the best range of parameters extracted from iteration number five, and these best ranges were imported into validation in one iteration [37].

The calibrated model was projected for the future climate using the predicted precipitation and surface air temperature for the period from 2015 to 2050 according to the scenario of moderate emissions (A1B). The original CFSR weather data were multiplied by the climate change factors for the gfdl_cm2_1.1, giss_model_e_r.1, cnrm_cm3.1, mri _cgcm2_3_2a.1, and bccr_bcm2_0.1 models and changed to the date 2050; then, SWAT-CUP was run for one iteration.

The future projected streamflow and sediment yield were compared with the streamflow of the 30 year base period (recorded streamflow from 1 January 1984 to 31 December 2013). Due to the unavailability of recorded sediments, the best sediment simulation for the 30 year base period was considered as the observed sediment to compare with future sediment prediction.

\section{Results and Discussion}

\subsection{Certainty of Weather Data and Climate Change Effect}

The recoded monthly precipitation in the Khanaqeen gauge station was correlated with the corresponding CFSR weather data according to data recorded from January 1984 to December 2002. The result of this correlation, illustrated in Figure 5, showed a good correlation between CFSR and the Khanaqeen gauge station data, with NSE, coefficient of determination $\left(R^{2}\right)$, and root-mean-square error (RMSE) of 0.70, 0.70, and 19.50, respectively.

According to Fuka et al. (2013) [29], SWAT performed well when using CFSR with NSE between observed and simulated streamflow, equal to 0.67 and 0.71, for the Cross River Watershed and Andreas Creek Watershed, respectively. In addition, the authors of [27] evaluated the calibrated streamflow, which was simulated using CFSR weather data in the Karuvannur Watershed in India, and they recommended using these data in ungauged watersheds.

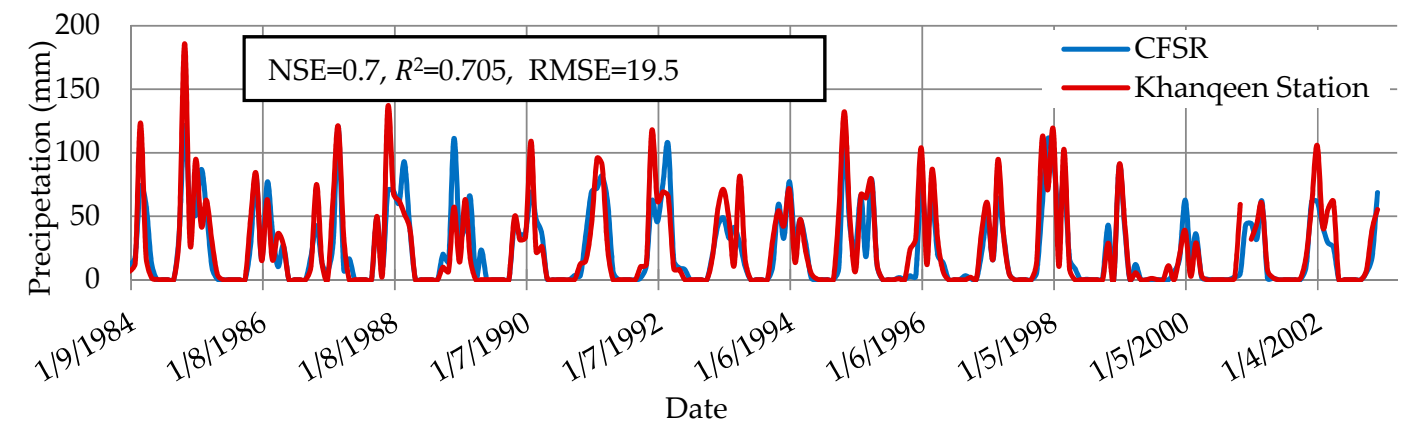

Figure 5. Correlation between CFSR and Khanaqeen gauge station for the period 1984 to 2002.

\subsection{Calibration, Validation, and Sensitivity Analysis}

The result of the sensitivity analysis for the Derbendkhan Watershed showed that 13 hydrologic parameters were most sensitive in streamflow simulations. These parameters and the sensitivity ranking in calibration processes are listed in Table 2. The Soil Conservation Service SCS streamflow curve number (CN2) was the most sensitive parameter in the Derbendkhan Watershed, followed by the available water capacity of the soil layer (SOL_AWC).

For the Hemrin Watershed, the results of the calibration and sensitivity analysis showed that eight hydrologic parameters are the most sensitive. The SCS streamflow curve number (CN2) was the 
most sensitive parameter in the watershed, followed by the available water capacity of the soil layer (SOL_AWC) (see Table 3).

Table 2. Calibrated hydrologic parameters for the Derbendkhan Watershed.

\begin{tabular}{|c|c|c|c|c|c|c|c|}
\hline Rank & Change & Parameter & Min. & Max. & Description & $t$-Test & $p$-Value \\
\hline 1 & $\mathrm{r}$ & CN2.mgt & -0.5 & 0.3 & $\begin{array}{c}\text { SCS streamflow curve } \\
\text { number }\end{array}$ & -20.08 & 0.00 \\
\hline 2 & $\mathrm{r}$ & SOL_AWC().sol & -0.3 & 0.5 & $\begin{array}{c}\text { Available water capacity of } \\
\text { the soil layer }\end{array}$ & 2.36 & 0.02 \\
\hline 3 & $\mathrm{r}$ & ESCO.hru & -0.3 & 0.5 & $\begin{array}{l}\text { Soil evaporation } \\
\text { compensation factor }\end{array}$ & -0.74 & 0.46 \\
\hline 4 & $\mathrm{r}$ & GWQMN.gw & -0.5 & 0.3 & $\begin{array}{l}\text { Threshold depth of water in } \\
\text { the shallow aquifer required } \\
\text { for return flow to occur (mm) }\end{array}$ & 0.72 & 0.47 \\
\hline 5 & $\mathrm{r}$ & GW_REVAP.gw & -0.5 & 0.3 & $\begin{array}{l}\text { Groundwater "revap" } \\
\text { coefficient }\end{array}$ & 0.49 & 0.63 \\
\hline 6 & $\mathrm{r}$ & REVAPMN.gw & -0.3 & 0.5 & $\begin{array}{l}\text { Threshold depth of water in } \\
\text { the shallow aquifer for } \\
\text { "revap" to occur (mm). }\end{array}$ & -0.49 & 0.63 \\
\hline 7 & $\mathrm{v}$ & GW_DELAY.gw & 30 & 450 & Groundwater delay (days) & 0.17 & 0.87 \\
\hline 8 & $\mathrm{v}$ & SFTMP.bsn & -10 & 10 & Snowfall temperature & -4.57 & 0.00 \\
\hline 9 & $\mathrm{v}$ & SMTMP.bsn & -10 & 10 & Snow melt base temperature & -5.30 & 0.00 \\
\hline 10 & $\mathrm{v}$ & SMFMX.bsn & 0 & 20 & $\begin{array}{l}\text { Maximum melt rate for snow } \\
\text { during year }\end{array}$ & -2.96 & 0.00 \\
\hline 11 & $\mathrm{v}$ & TIMP.bsn & 0 & 20 & $\begin{array}{c}\text { Snow pack temperature } \\
\text { lag factor }\end{array}$ & -0.53 & 0.60 \\
\hline 12 & $\mathrm{v}$ & SMFMN.bsn & 0 & 1 & $\begin{array}{c}\text { Minimum melt rate for snow } \\
\text { during the year }\end{array}$ & -1.37 & 0.17 \\
\hline 13 & $\mathrm{v}$ & ALPHA_BF.gw & 0 & 1 & Base flow alpha factor (days) & 0.77 & 0.44 \\
\hline
\end{tabular}

Table 3. Calibrated hydrologic parameters for the Hemrin Watershed.

\begin{tabular}{cccccccc}
\hline Rank & Change & Parameter & Min. & Max. & Description & $t$-Test & $p$-Value \\
\hline 1 & $\mathrm{r}$ & CN2.mgt & -0.5 & 0.4 & $\begin{array}{c}\text { SCS streamflow curve } \\
\text { number }\end{array}$ & -0.12 & 0.91 \\
\hline 2 & $\mathrm{r}$ & SOL_AWC().sol & -0.5 & 0.5 & $\begin{array}{c}\text { Available water capacity of } \\
\text { the soil layer }\end{array}$ & -0.24 & 0.81 \\
\hline 3 & $\mathrm{r}$ & ESCO.hru & -0.5 & 0.5 & $\begin{array}{c}\text { Soil evaporation } \\
\text { compensation factor }\end{array}$ & -0.53 & 0.61 \\
\hline 4 & $\mathrm{r}$ & GWQMN.gw & -0.5 & 0.5 & $\begin{array}{c}\text { Threshold depth of water in } \\
\text { the shallow aquifer required } \\
\text { for return flow to occur (mm) }\end{array}$ & 0.90 & 0.38 \\
\hline 5 & $\mathrm{r}$ & GW_REVAP.gw & -0.5 & 0.5 & $\begin{array}{c}\text { Groundwater “revap" } \\
\text { coefficient }\end{array}$ & 1.15 & 0.27 \\
\hline 7 & $\mathrm{r}$ & REVAPMN.gw & -0.5 & 0.5 & $\begin{array}{c}\text { Threshold depth of water in } \\
\text { the shallow aquifer for } \\
\text { "revap" to occur (mm). }\end{array}$ & 1.71 & 0.11 \\
\hline 8 & $\mathrm{r}$ & RCHRG_DP.gw & -0.5 & 0.5 & $\begin{array}{c}\text { Deep aquifer percolation } \\
\text { fraction. }\end{array}$ & 2.21 & 0.04 \\
\hline
\end{tabular}

According to Moriasi et al. (2007) [28], if the NSE is greater than 0.5, the simulation is satisfactory, while a good simulation should have an NSE greater than 0.75 . Consequently, the calibrated and validated streamflow, the accepted SWAT model, of the Derbendkhan Watershed with daily-based NSE, $R^{2}$, P-factor, and R-factor for calibration (validation) of 0.61 (0.53), $0.62(0.68), 0.84(0.21)$, and 1.00 
(0.77), respectively, is shown in Figure 6. For both models, the results of calibration and validation were considered acceptable simulations. Also, for the Hemrin Watershed, the best calibrated and validated model was accepted with NSE, $R^{2}$, P-factor, and R-factor of calibration (validation) of $0.60(0.62)$, $0.61(0.58), 0.70(0.76)$, and $0.92(0.55)$, respectively, as shown in Figure 7.

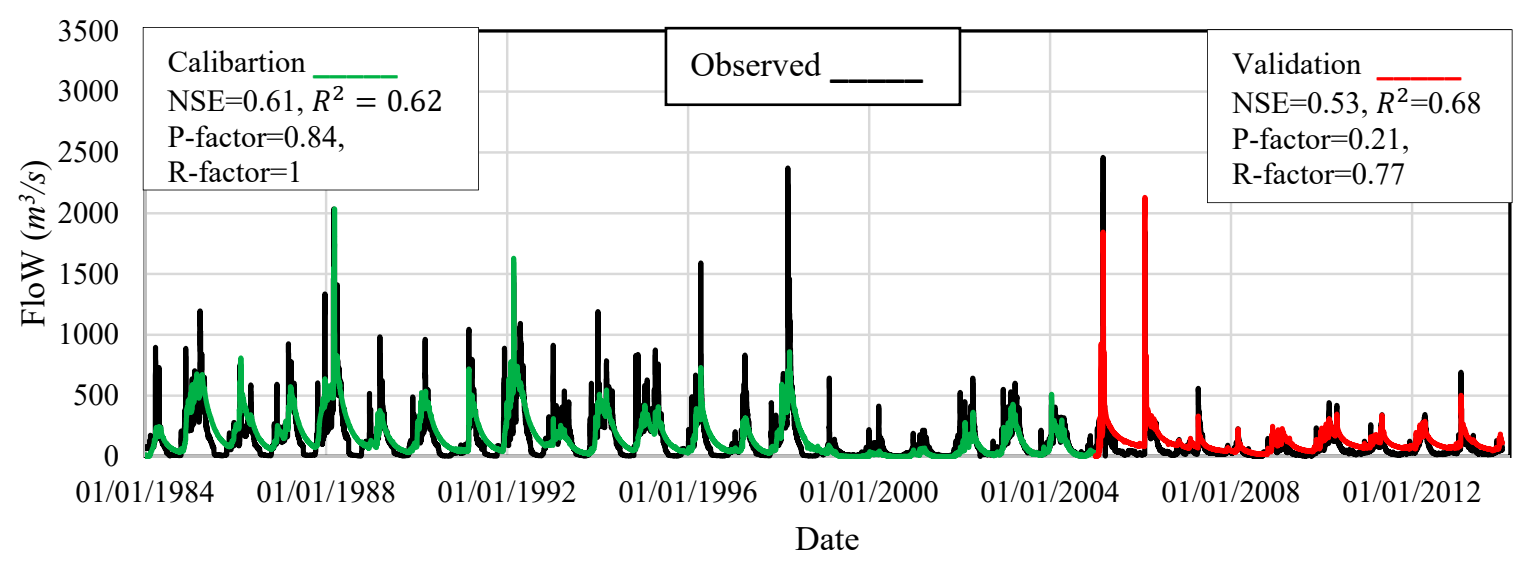

Figure 6. Calibrated and validated streamflow of the Derbendkhan Watershed.

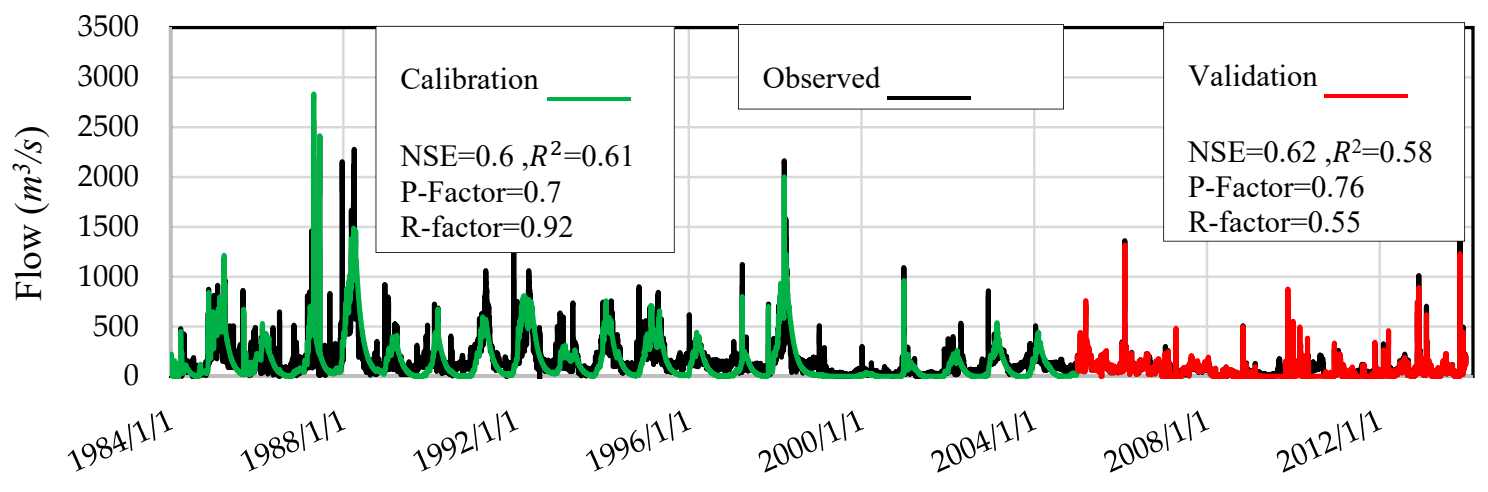

Date

Figure 7. Calibrated and validated streamflow of the Hemrin Watershed.

\subsection{Temporal Distribution of Streamflow and Sediment Yield}

The computed streamflow temporal distribution of the Derbendkhan Watershed for the period from 1984 to 2013 is shown in Figure 8. The streamflow had a negative trend from around $150 \mathrm{~m}^{3} / \mathrm{s}$ in the middle of the 1980 s to $50 \mathrm{~m}^{3} / \mathrm{s}$ in the middle of the 2010s.

In spite of the decrease in streamflow, the sediment yield of the Derbendkhan Watershed had a positive trend (see Figure 9). The largest sediment peaks occurred in the beginning and middle of 2000. This is because the impact of climate change (decreasing the precipitation and increasing the air temperature) contributed to hiding the effective land cover catch of the surface soil.

For the Hemrin Watershed, Figure 10 shows that the streamflow had a negative trend with $\sim 250 \mathrm{~m}^{3} / \mathrm{s}$ in the middle of the 1980 s to $\sim 125 \mathrm{~m}^{3} / \mathrm{s}$ in the mid-2010s. It is obvious that the streamflow will decrease until 2050 in the Diyala River as a result of climate change, so it is important to consider this impact in future water resource projects.

The sediment yield peaks for the Hemrin Watershed significantly increased by the middle of 2000, as shown in Figure 11. This was because of climate change resulted in a lack of precipitation and an increase in air temperature, which contributed to desertification within the Hemrin Watershed. 


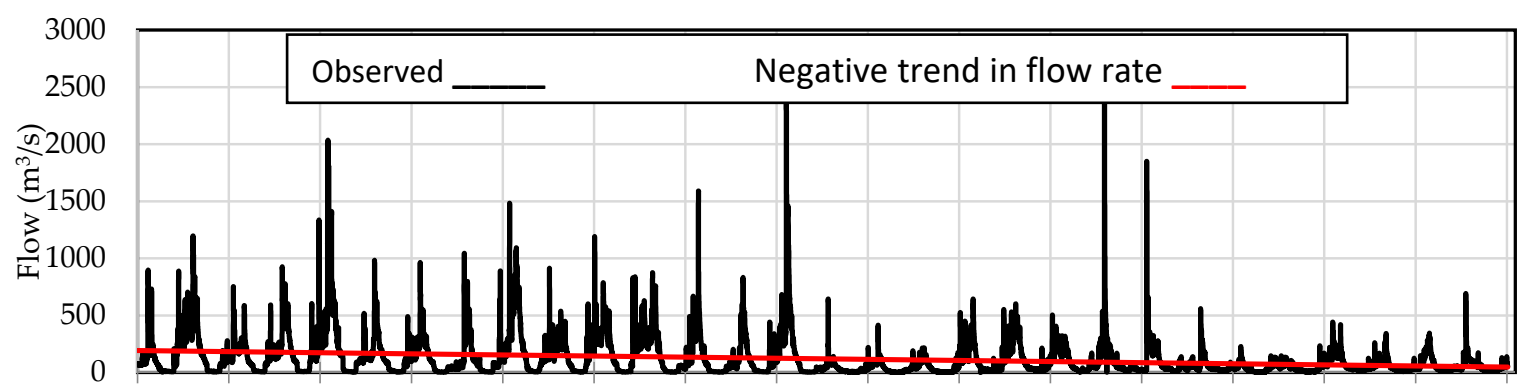

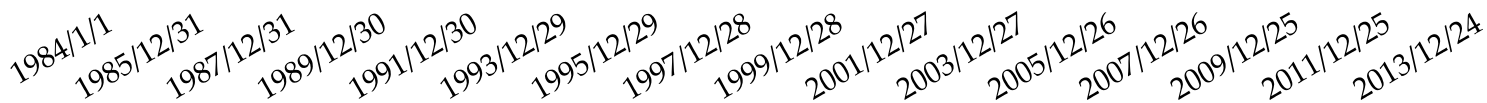

Date

Figure 8. Temporal distribution of the streamflow of the Derbendkhan Watershed for the period from 1984 to 2013.

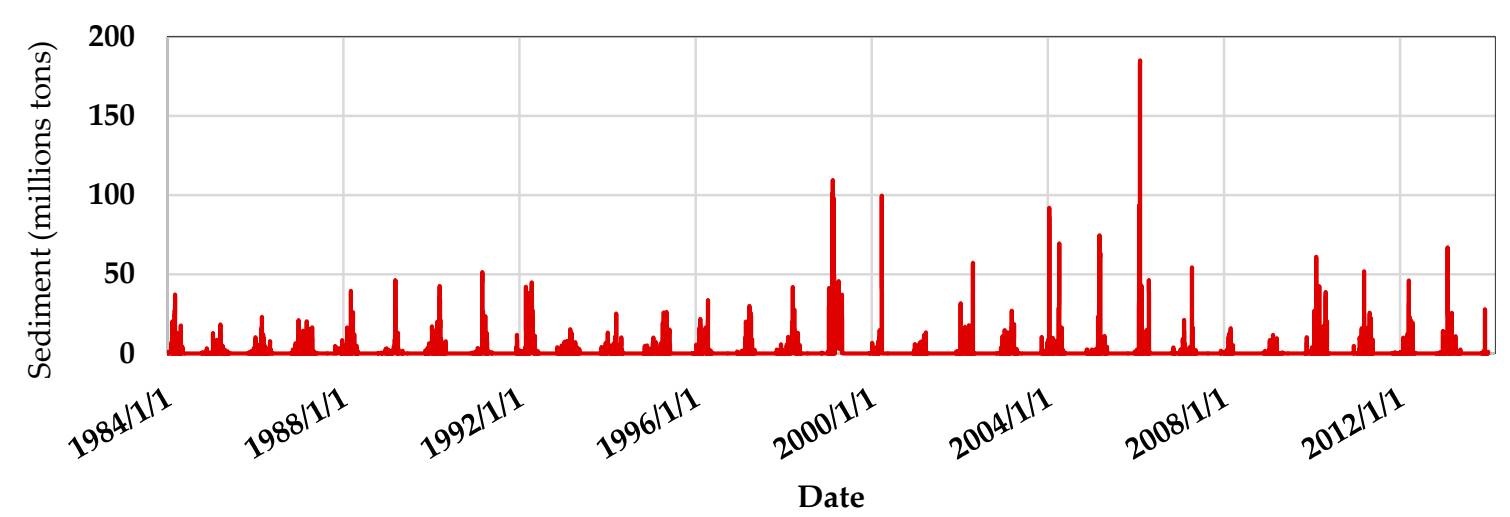

Figure 9. Best simulated sediment inflow into the Derbendkhan Reservoir.

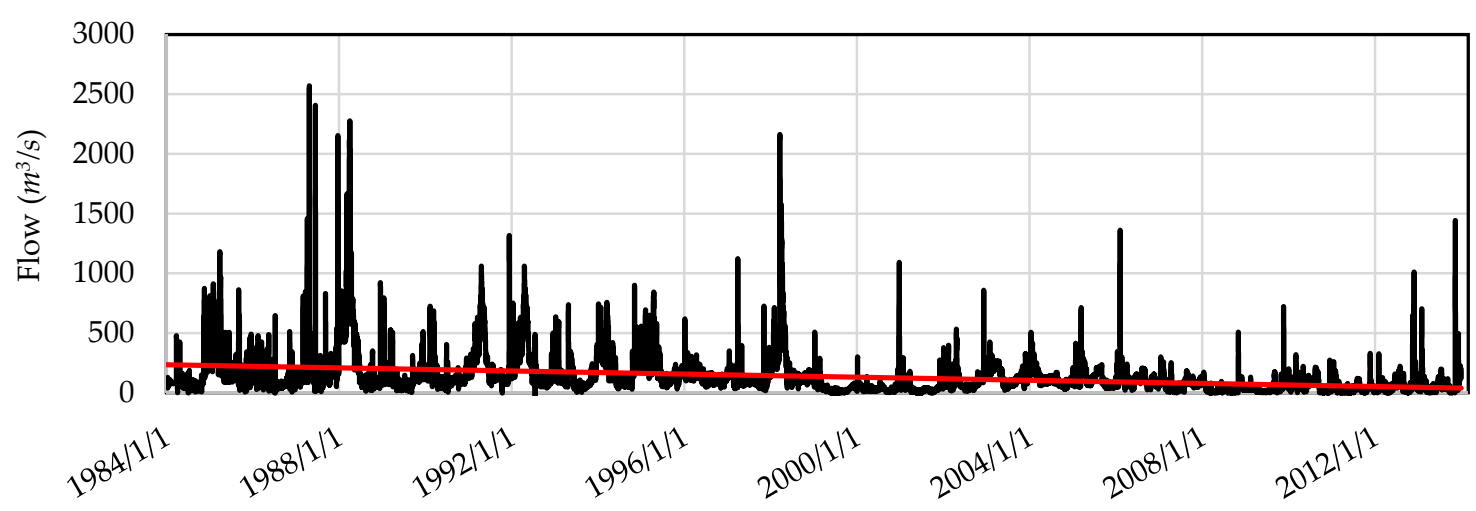

Date

Figure 10. Temporal distribution of the streamflow of the Hemrin Watershed for the period from 1984 to 2013. 


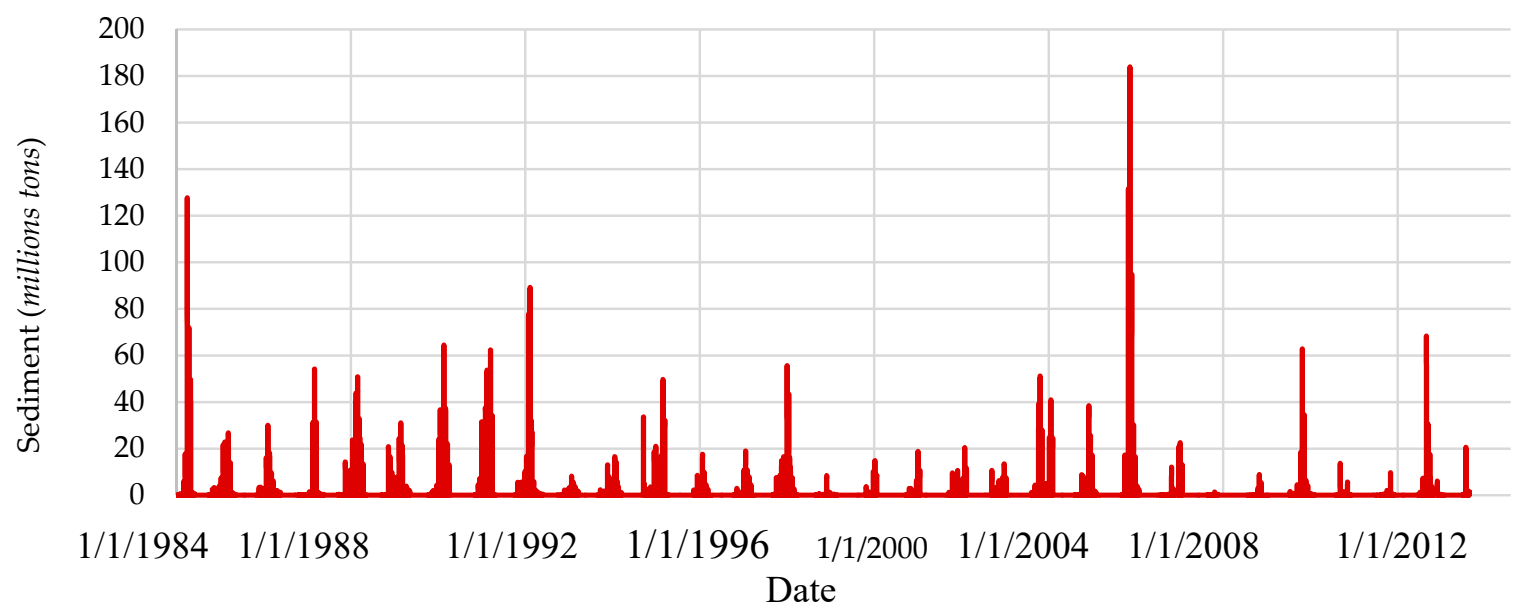

Figure 11. Simulated sediment inflow into the Hemrin Reservoir.

\subsection{Impact of Climate Change on Streamflow and Sediment Yield}

The result of climate change on the average monthly streamflow in the Derbendkhan and Hemrin Watersheds for the period from 2015 to 2050 showed a significant decrease in the streamflow. Figures 12 and 13 show that the average decrease in streamflow for the gfdl_cm2_1.1, giss_model_e_r.1, cnrm_cm3.1, mri_cgcm2_3_2a.1, and bccr_bcm2_0.1 climate models were $49 \%$ and $20 \%$, respectively. This result agrees with that of Abbas et al. (2016) [7], where they concluded, according to the results of six climate models, that the streamflow will decrease at the Derbendkhan Dam by $47 \%$ until 2064 . Generally, the simulated streamflow for all climate models showed the same behavior, except the cnrm_cm2-3.1 model, which showed a significant increase in streamflow. This is because this model predicted more precipitation than the other models. However, the author of Abbas et al. (2016) [7] concluded that the streamflow will decrease at the Derbendkhan Dam by $47 \%$ until 2064, according to the results of six climate models, a result which is compatible with the findings of this study.

Figures 14 and 15 show the impact of climate change on the monthly average sediment yield for the period from 2015 to 2050 for the Derbendkhan and Hemrin Watersheds. In the average of the five climate models the sediment will decrease by $43.7 \%$ and $30 \%$, respectively, compared with the sediment income for the period from 1984 to 2013.

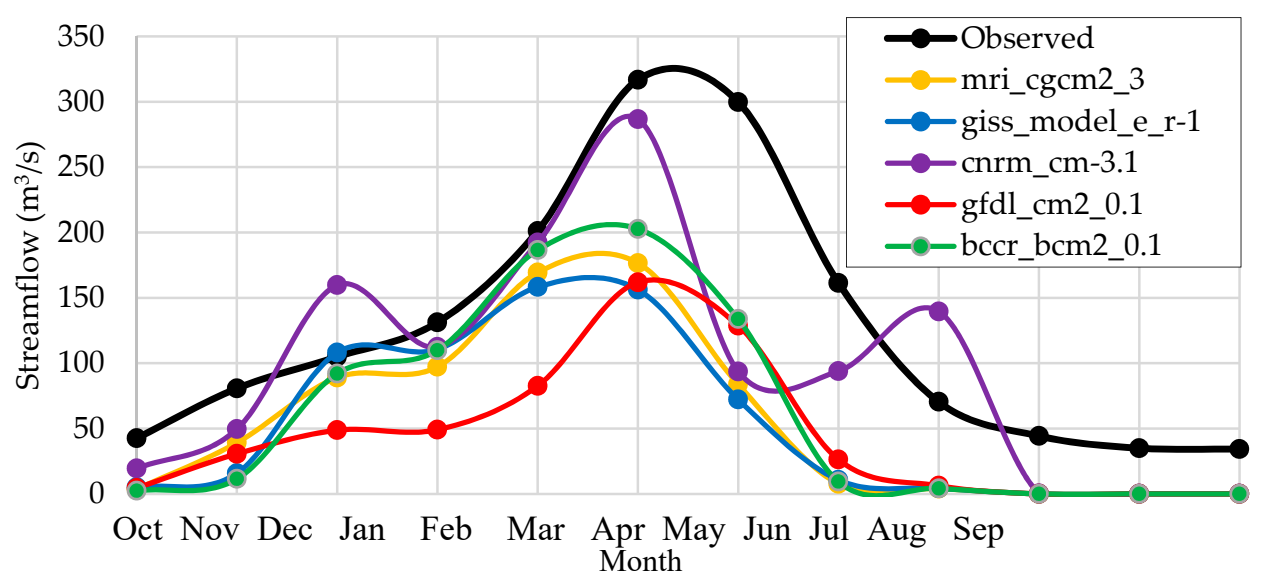

Figure 12. Impact of climate change on simulated streamflow of the Derbendkhan Watershed for the period from 2015 to 2050. 


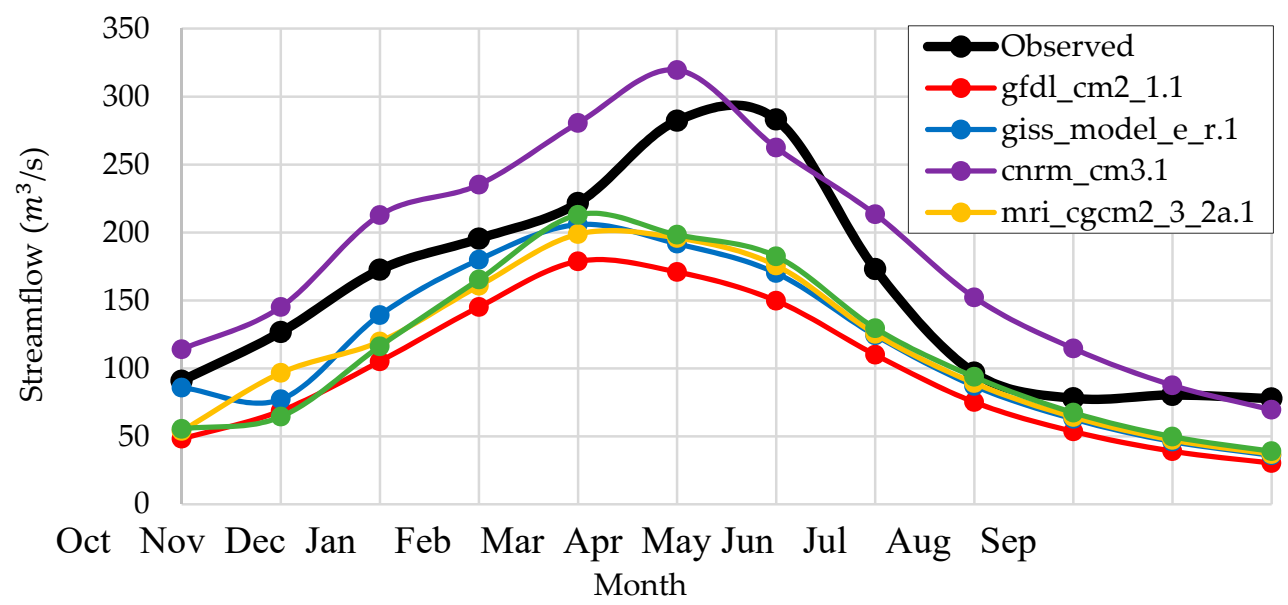

Figure 13. Impact of climate change on simulated streamflow of the Hemrin Watershed for the period from 2015 to 2050.

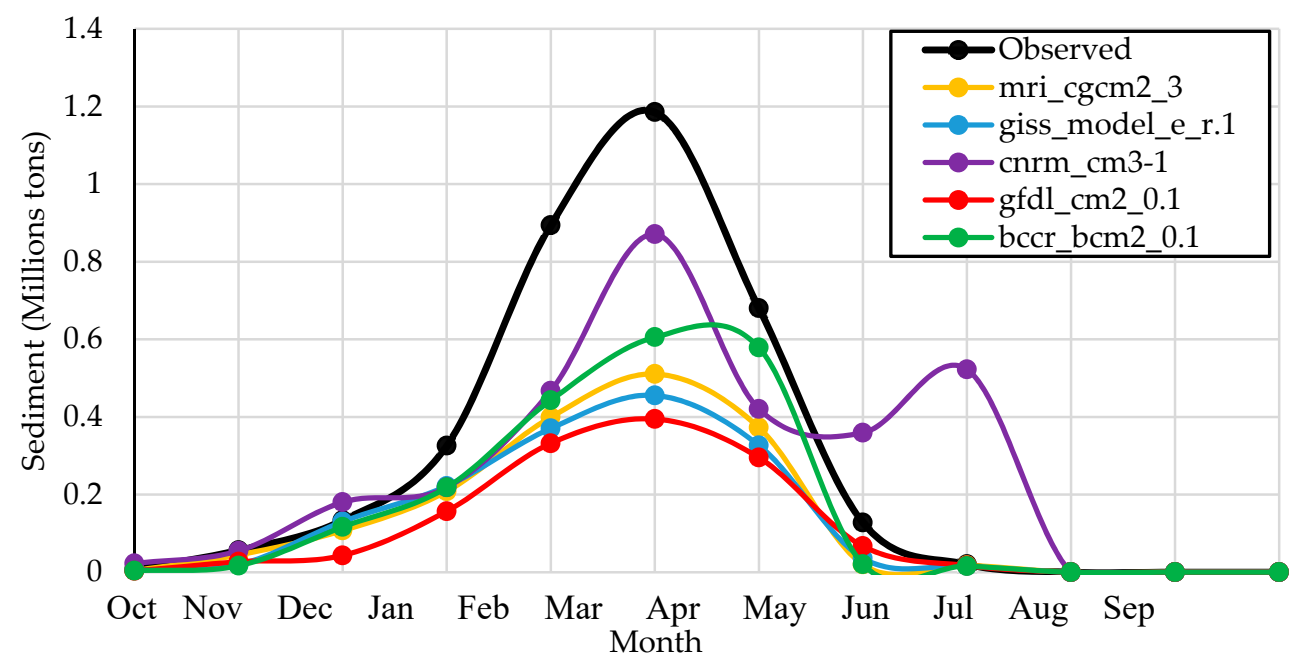

Figure 14. Impact of climate change on simulated sediment of the Derbendkhan Watershed for the period from 2015 to 2050.

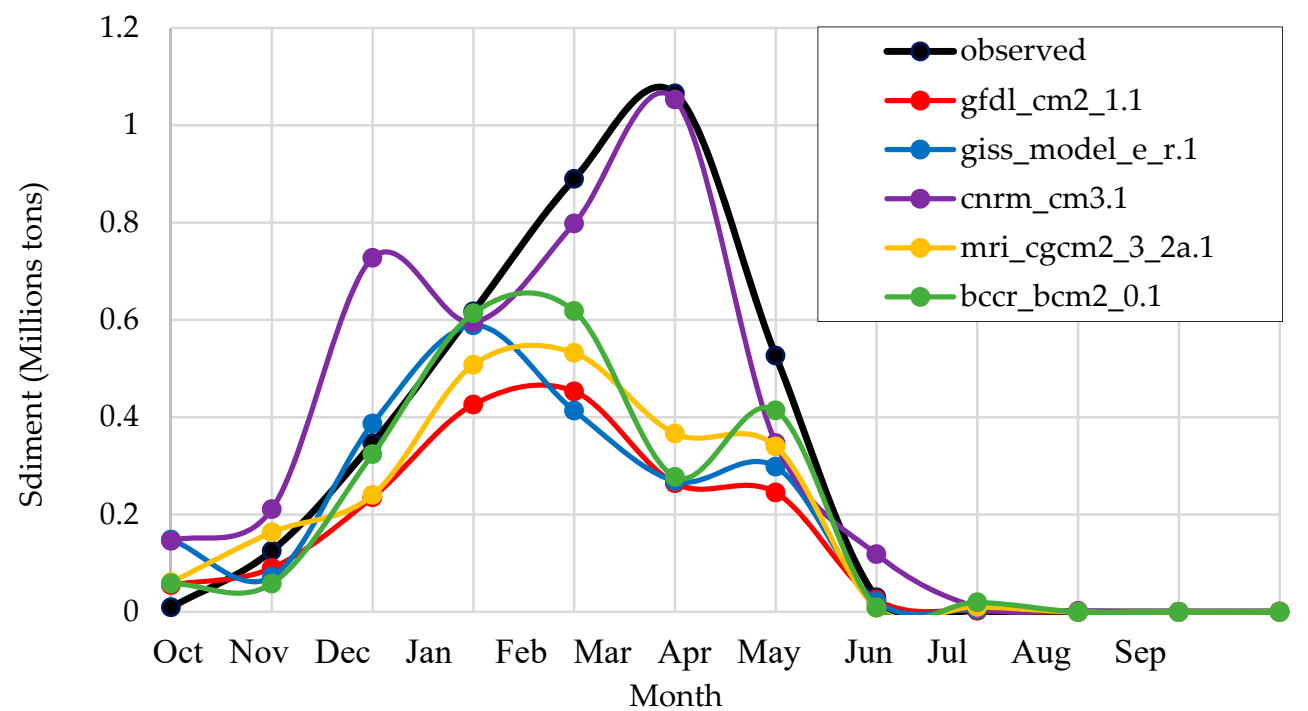

Figure 15. Impact of climate change on simulated sediment of the Hemrin Watershed for the period from 2015 to 2050. 
In addition, all climate models showed the same behavior in all 12 months except the cnrm_cm-3.1 model, the simulated sediment of which was estimated to be higher than the other climate models.

Table 4 shows the percentages of decrease in the simulated streamflow and sediment yield for the Derbendkhan and Hemrin Watersheds under the impact of climate change in the future (2015-2050). This table illustrated that the average streamflow (sediment yield) inflow into the Derbendkhan and Hemrin Reservoirs will decrease to $49 \%(43.7 \%)$ and $20 \%$ (30\%), respectively. This negative trend in water resources of the Diyala River can be ascribed to the impact of climate change.

Table 4. Impact of climate change on the simulated streamflow and sediment yield for the Hemrin and Derbendkhan Watersheds.

\begin{tabular}{ccc}
\hline Watershed & Streamflow Decreasing (\%) & Sediment Yield Decreasing (\%) \\
\hline Hemrin & 20 & 30 \\
Derbendkhan & 49 & 43.7 \\
\hline
\end{tabular}

\subsection{Spatial Distribution of Streamflow and Sediment}

SWAT allowed investigating the sources of streamflow and sediment yield according to the sub-basin contribution to the total streamflow. This process showed that the middle and southern parts of the Derbendkhan Watershed are greater streamflow producers than the other parts of watershed. In spite of the Iraqi part of the Derbendkhan Watershed representing 20\% of the total watershed area, it contributed only $10.4 \%$ of the total streamflow for the 30-year period between 1984 and 2013. Moreover, the soil of the type D hydrologic group, which had a higher streamflow rate than the other types, dominates the soil in these parts. Also, agricultural and forested land cover dominates in these parts. Figure 16 shows the average streamflow at the sub-basin level of the Derbendkhan Watershed for the period from 1984 to 2013.

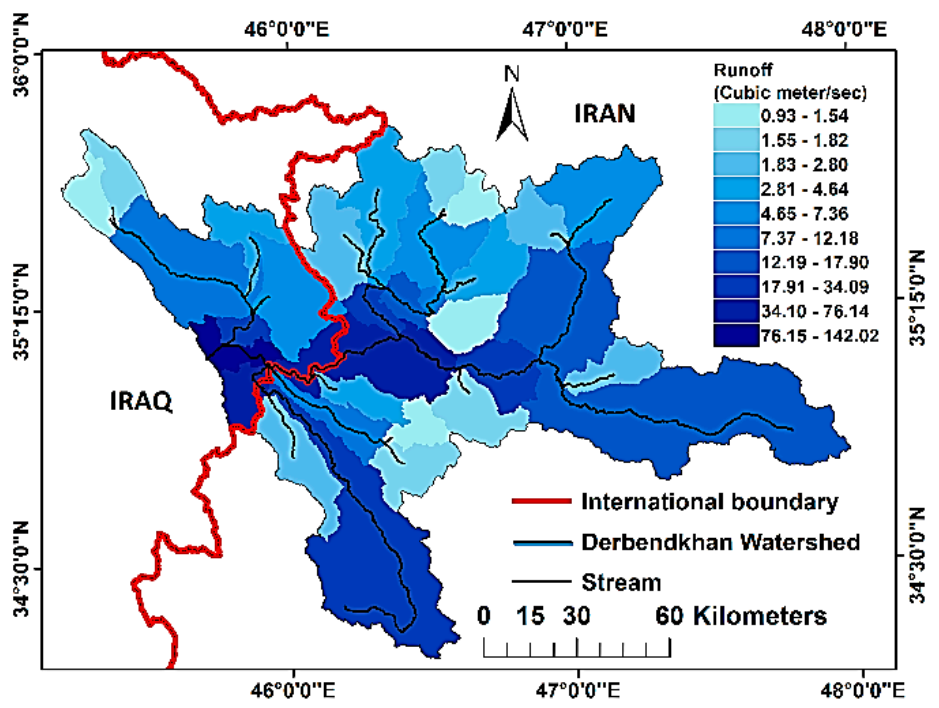

Figure 16. Average streamflow for the Derbendkhan Watershed at the sub-basin level for the period from 1984 to 2013.

Figure 17 shows the spatial distribution of sediment yield within the Derbendkhan Watershed for the period from 1984 to 2013. This figure shows that the Iraqi part of the watershed contributed only $10 \%$ of the total sediment produced by the Derbendkhan Watershed. In addition, a large amount of the sediment was produced by the middle part of the watershed. This is because the middle parts of the Derbendkhan Watershed have steep slopes with pasture land cover that allow the surface streamflow to erode the surface soil. The Iraqi parts of the watershed have mild slopes with frosted and agricultural land cover, so this part contributed to a small amount of sediment reaching the Derbendkhan Reservoir. 
The same analysis was done for the Hemrin Watershed. Figure 18 shows that, for the average streamflow for the period from 1984 to 2013, it is clear that the streamflow was concentrated in the center and northern parts of the watershed. However, the Iraqi part of the watershed represented $68 \%$ of the total watershed area, but this part contributed to $71 \%$ of the average streamflow simulated for the period from 1984 to 2013. This is because these parts represent the highest ground surface elevation, which is considered to be more isohyetal than the other parts of the watershed.

Figure 19 illustrates the spatial distribution of sediment yield within the Hemrin Watershed. It is clear that the steep slopes of the mountainous regions of the watershed (see Figure 2) contributed most to the sediment yield, with approximately 5-40 tons/ha of simulated sediment on average for the 30 years from 1984 to 2013. Also, open shrub land is the dominant land cover of the mountainous regions in the Hemrin Watershed, which contributes to less surface soil stabilization against surface streamflow force. In spite of this, barren land is the dominant land cover in flat regions of the watershed, but these regions contributed less to the sediment rate compared with the mountainous regions.

For both watersheds, most of the sediment yield came from the Iranian parts of the watersheds, so some conventional sediment mitigation was modeled in the Iraqi part of the Hemrin Watershed, which represented the part with $60 \%$ of the total sediment yield in this watershed.

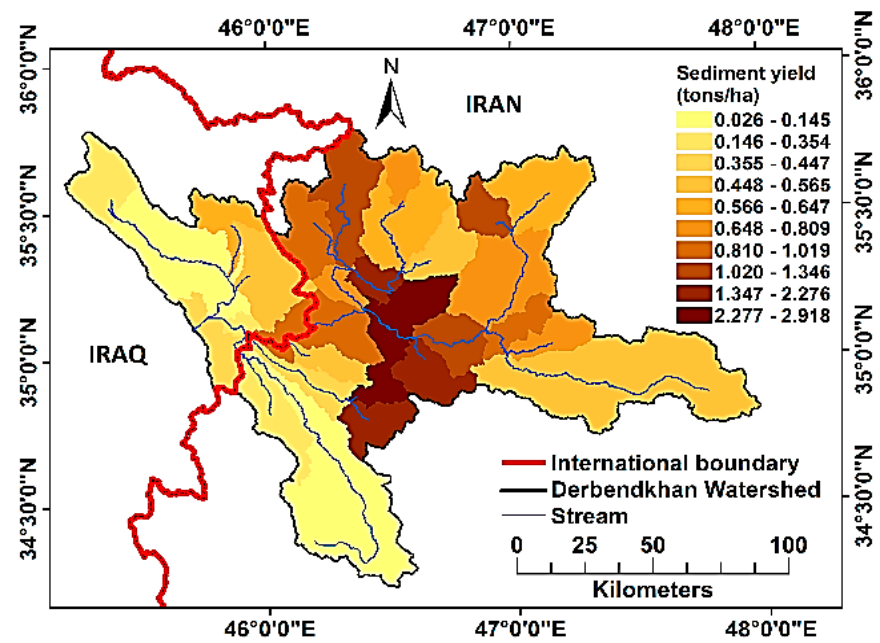

Figure 17. Average sediment yield for the Derbendkhan Watershed at the sub-basin level for the period from 1984 to 2013.

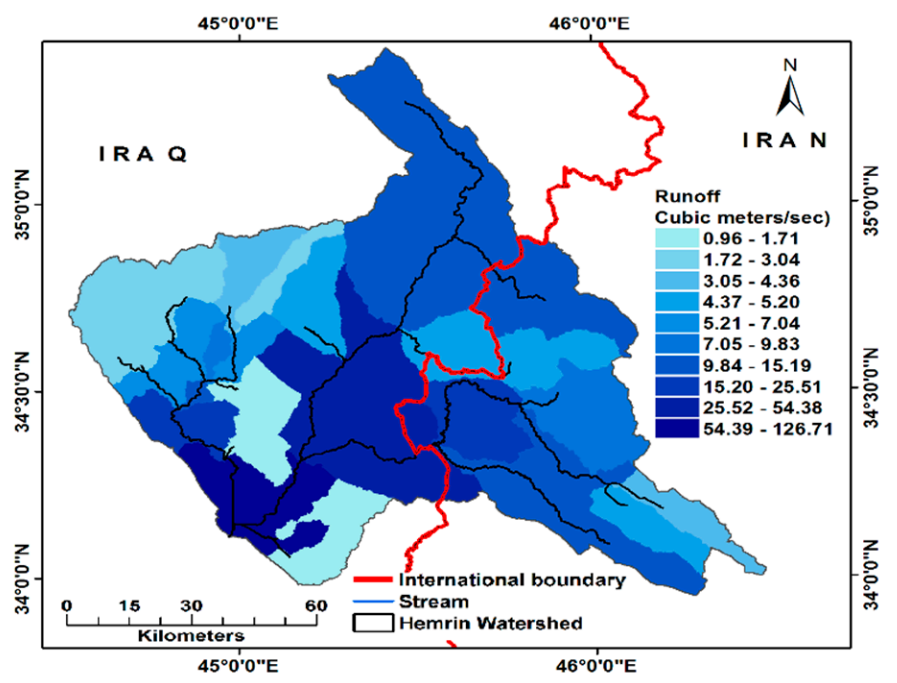

Figure 18. Average streamflow for the Hemrin Watershed at the sub-basin level for the period from 1984 to 2013. 


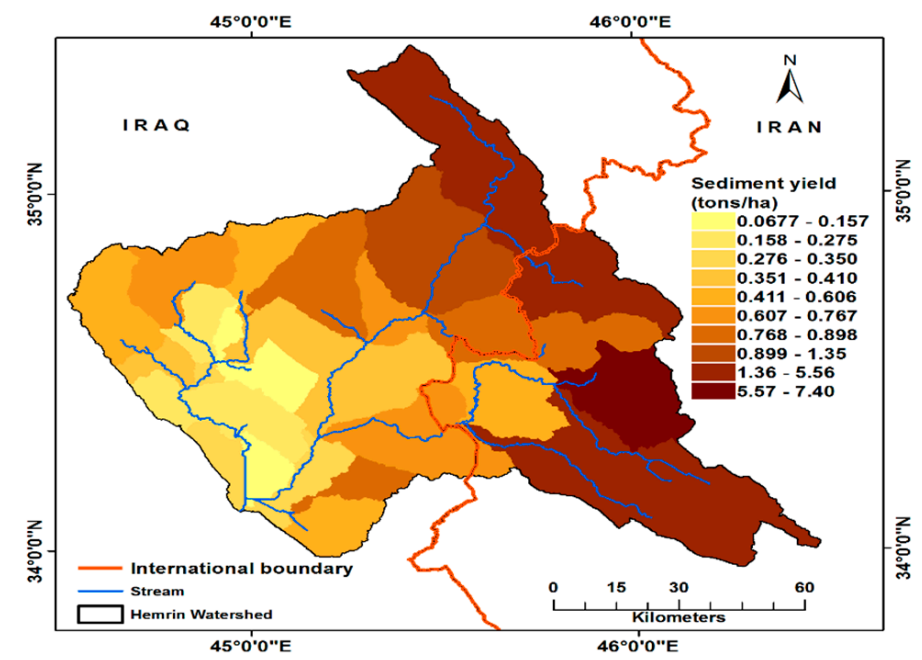

Figure 19. Average sediment yield at the sub-basin level for the period from 1984 to 2013 for the Hemrin Watershed.

\subsection{Mitigation of Sediment Yield}

According to the future prediction of water resources in the Diyala River based on the conditions, it is necessary to maintain the quantity and quality of water in the Diyala River. Therefore, some conventional sediment yield mitigation techniques were applied in the most sediment-producing parts of the Hemrin Watershed. Three scenarios of using forestation instead of open shrub land found in original land cover were investigated (Figures 20-22). In this process, the mitigation of sediment yield in the Derbendkhan Watershed was excluded because only $20 \%$ of the watershed is located in Iraq. Furthermore, this small area is covered by cropland (see Figure 3).

The spatial distribution of sediment yield showed that the northern parts of the Hemrin Watershed are the biggest sediment producers. This can be ascribed to the steep slopes and land cover of open shrub land in these parts, so the optimum solution is forestation.

The following three scenarios were used to mitigate the sediment yield in the Hemrin Watershed. However, the shape and area of mitigation were done according to the shape and area of the sub-basin of the highest sediment yield. Mitigation-1 (M-1) includes reforestation of the northern part of the watershed, as shown in Figure 20. Mitigation-2 (M-2) includes reforestation of the northern part and some of the middle part of the watershed, as shown in Figure 21. Mitigation-3 (M-3) includes reforestation of the northern part and some of the middle and southern parts of barren land of the watershed, as shown in Figure 22.

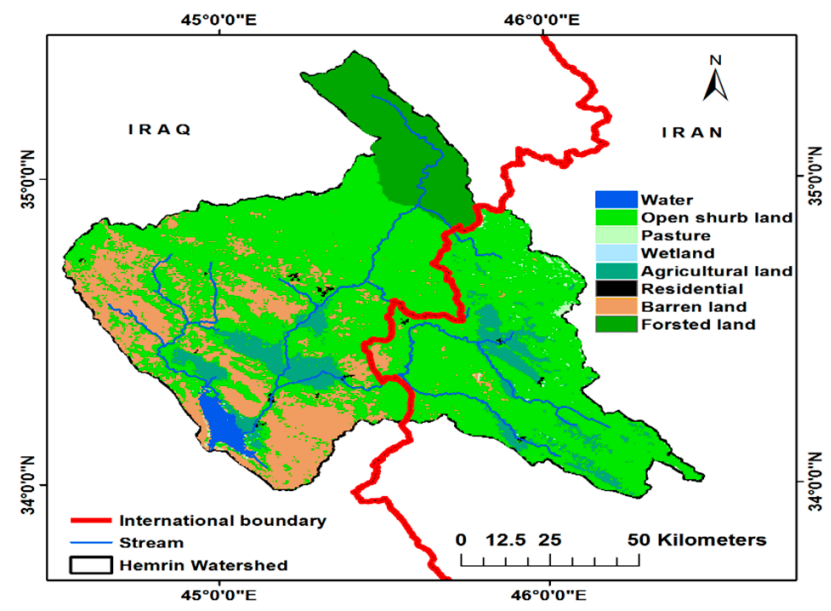

Figure 20. Senario-1 (M-1) of sediment mitigation in the Hemrin Watershed. 


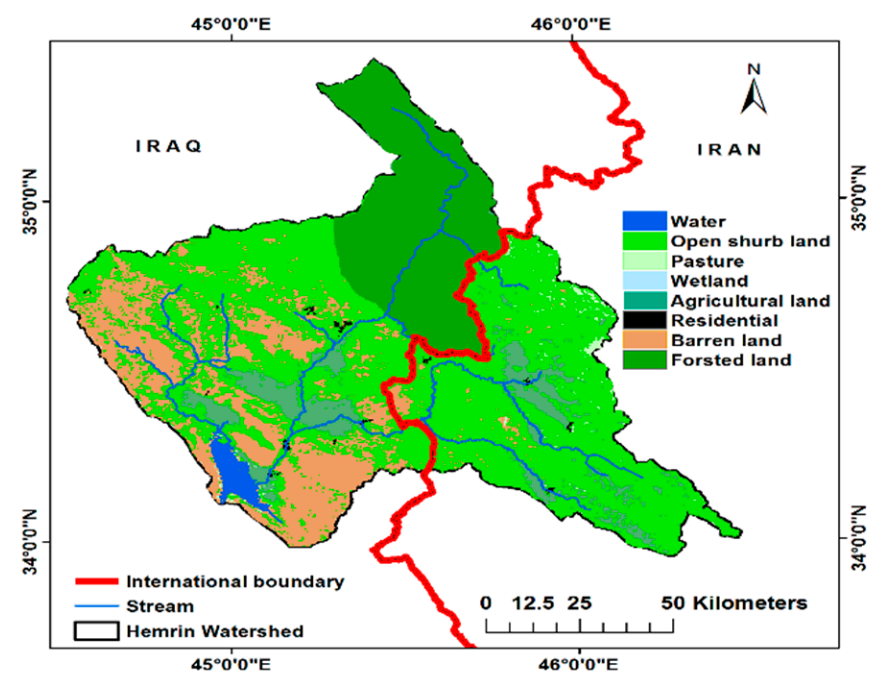

Figure 21. Senario-2 (M-2) of sediment mitigation in the Hemrin Watershed.

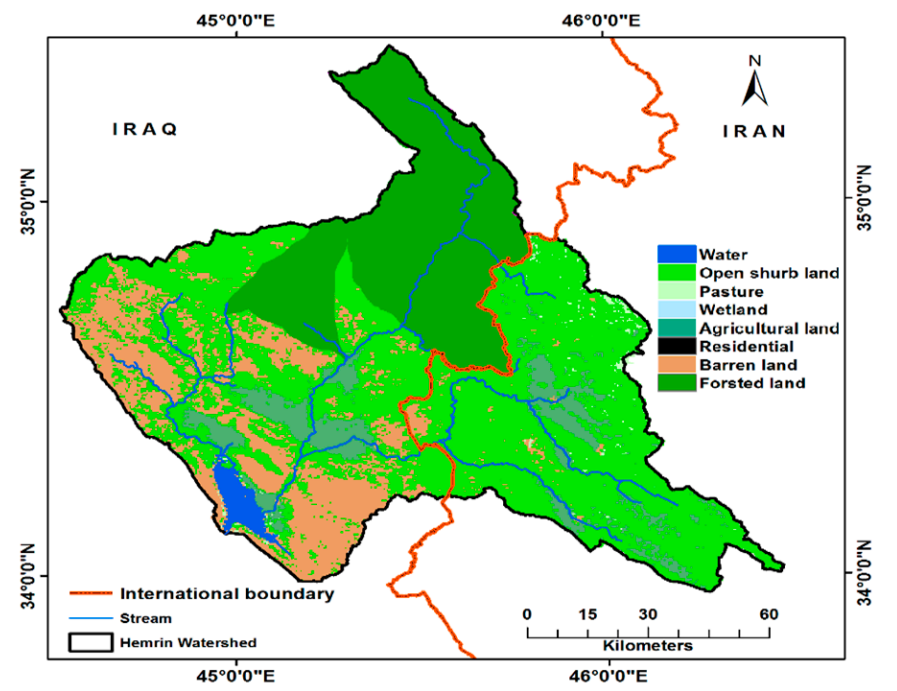

Figure 22. Senario-3 (M-3) of sediment mitigation in the Hemrin Watershed.

The computed stream flow and sediment yield distributions of the mitigation scenarios are shown in Figures 23-27. It is clear that sediment mitigation had a significant impact on the streamflow and sediment yield. The streamflow without mitigation was $125.5 \mathrm{~m}^{3} / \mathrm{s}$. This magnitude will decrease to $119.7,118.5$, and $116.3 \mathrm{~m}^{3} / \mathrm{s}$ for M-1, M-2, and M-3, respectively. While the sediment yield without mitigation was 2.5 million tons per year, this amount will decrease to $2.3,2.3$, and 2.3 million tons per year for M-1, M-2, and M-3, respectively (see Figure 23). Hence, the best sediment yield mitigation scenario is the M-1 scenario. However, no significant sediment reduction was obtained when applying the M-2 and M-3 scenarios compared with the reduction achieved by applying the M-1 scenario. Also, increasing the deforestation area requires more expenditures and has few benefits. The computed sediment yield spatial distribution of the considered mitigation scenarios are shown in Figures 25-27. 


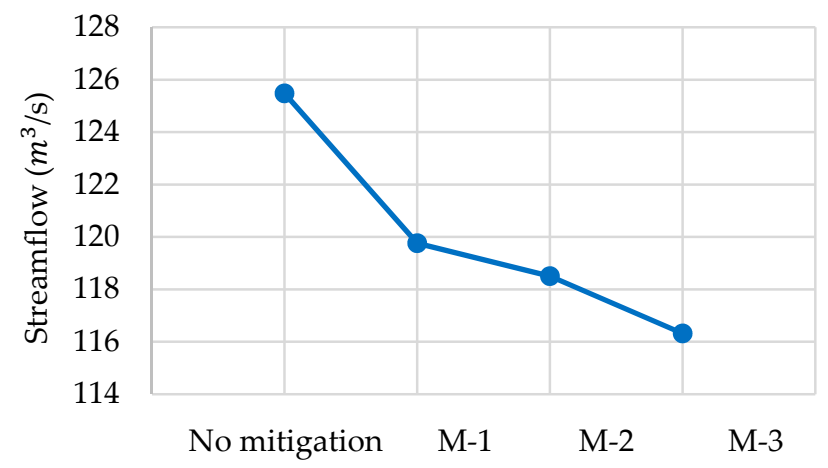

Figure 23. Simulated streamflow in the case of land cover mitigation in the Hemrin Watershed.

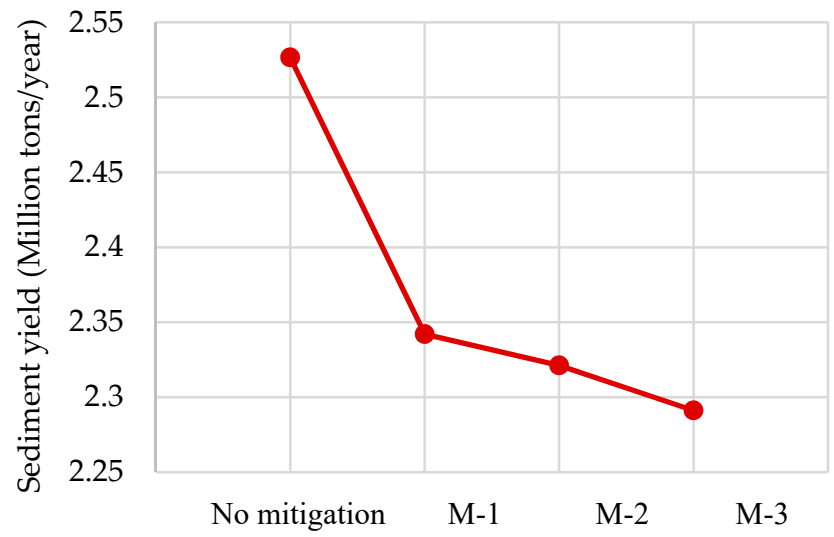

Figure 24. Simulated sediment yield in the case of land cover mitigation in the Hemrin Watershed.

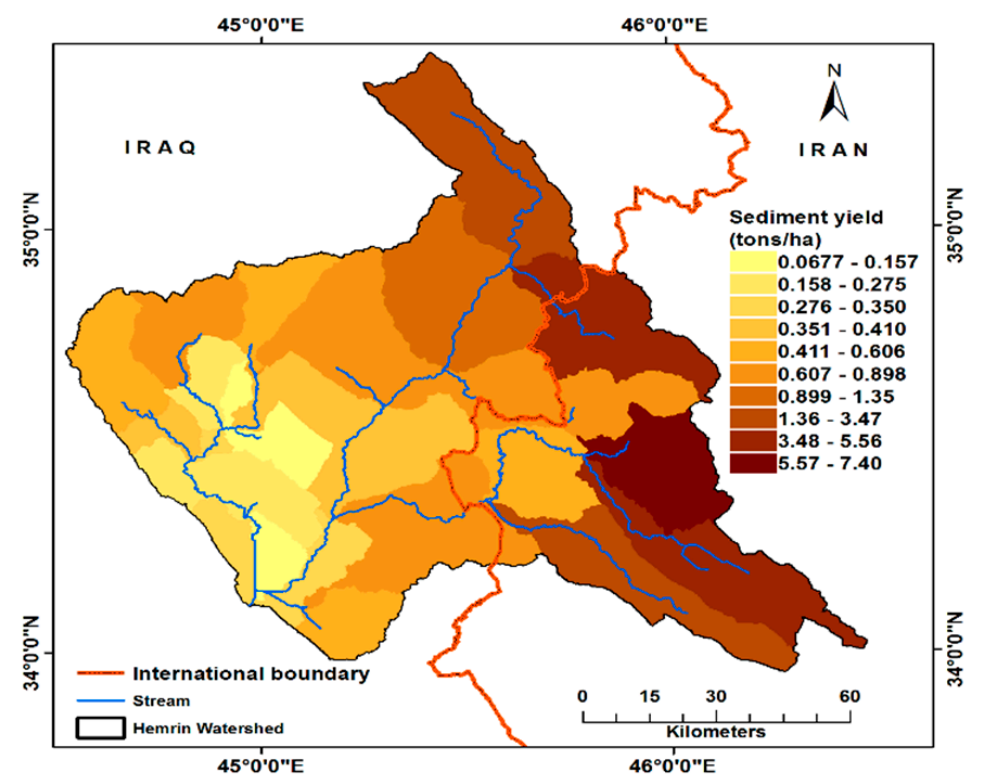

Figure 25. Result of senario-1 (M-1) of sediment mitigation. 


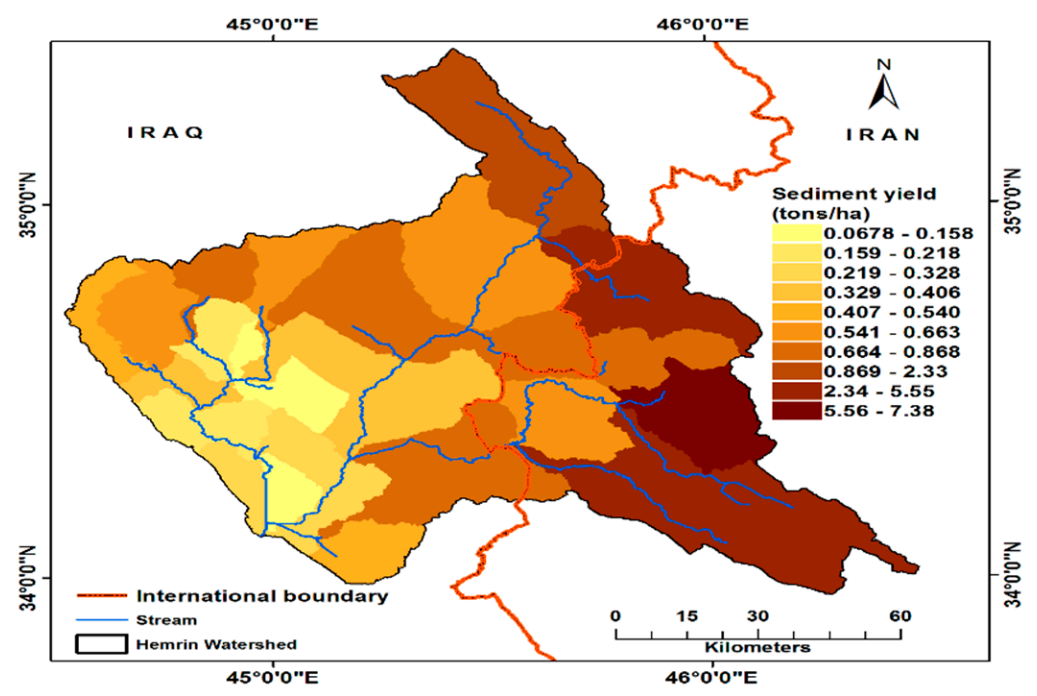

Figure 26. Result of senario-2 (M-2) of sediment mitigation.

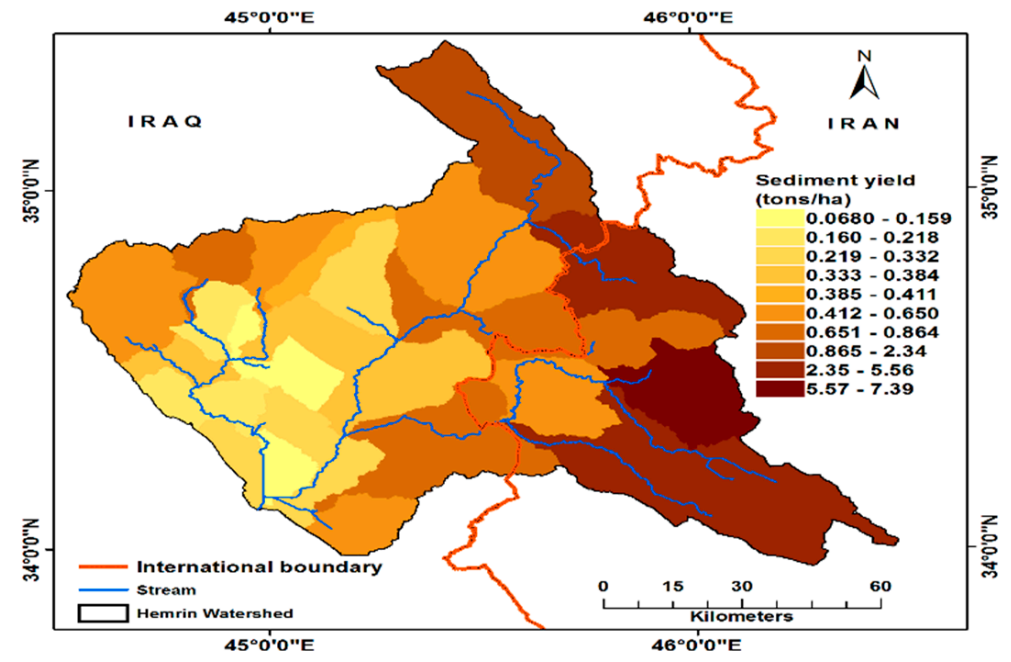

Figure 27. Result of senario-3 (M-3) of sediment mitigation.

\section{Conclusions}

In this study, the SWAT model was implemented in the Diyala River to show the impact of climate change on the streamflow and sediment yield. The CFSR weather data are considered to be a reliable source of weather data for the Derbendkhan Watershed and provided acceptable streamflow simulations when using the SWAT model. The results of the investigated present and future climate conditions showed that the surface water resources in the Derbendkhan and Hemrin Watersheds will decrease by approximately $49 \%$ and $20 \%$, respectively, under the impact of climate change until year 2050. This can be attributed to the decrease in precipitation and increase of the surface air temperature, while the sediment yield will decrease to $43.7 \%$ and $30 \%$ for the Derbendkhan and Hemrin Watersheds, respectively. In addition, the peaks of sediment yield increased after 2000. This is because of the poor land cover catching the surface soil against the streamflow force for this period because of climate change. Therefore, this can be negatively reflected by the operation of sediment gates in the future.

Moreover, the middle and southern parts of the Derbendkhan Watershed are the biggest streamflow producers as a result of being highly isohyetal compared with the other parts of the watershed, whereas most of the sediment yields from the steep and barren land parts of the watershed are located in the middle parts. Most of the soil types of the Derbendkhan Watershed are soils of the type D hydrologic group, which has the highest rate of streamflow and thus can yield more sediment due to 
erosion. The streamflow of the Hemrin Watershed concentrates in the middle and northern parts of the watershed and most of the sediment yields are from the steep and barren land regions of the watershed.

The results of this study can be used for planning future projects related to water resources. More investigations should be done for groundwater considering climate change impacts. However, cooperation between Iraq and Iran is needed for hydrologic data exchange, planning for sediment mitigation, and justice in water usage during the dry and wet seasons. This study explored some extreme hydrologic events, such as the highest peaks of streamflow and sediment occurring in the Diyala River, so it is recommended to investigate modified dam designs, specifically, sediment gates and spillway capacity, under climate change conditions. In addition, since the time series of sediment yield is not very extensive, comprehensive monitoring program for the sediment must be applied. Moreover, further studies related with this topic is required.

Author Contributions: Conceptualization, M.S.A.-K. and R.D.A.-C.; methodology, M.S.A.-K. and R.D.A.-C.; software, R.D.A.-C.; validation, R.D.A.-C.; formal analysis, M.S.A.-K.; investigation, M.S.A.-K. and R.D.A.-C.; M.S.A.-K.; data curation, M.S.A.-K.; writing-original draft preparation, R.D.A.-C.; writing-review and editing, M.S.A.-K.; visualization, M.S.A.-K. and R.D.A.-C.; supervision, M.S.A.-K.; project administration, M.S.A.-K. and R.D.A.-C.

Funding: This research received no external funding.

Acknowledgments: The authors wish to thank the technical and faculty staff of the Department of Civil Engineering at the University of Technology-Iraq for the valuable support and scientific assistance. Also, we would like to express our appreciation to the Ministry of Water Resources/National Center of Water Resources Management, Iraq for their help in facilitating our research task through providing the required data and conducting the field study.

Conflicts of Interest: The authors declare no conflict of interest.

\section{References}

1. IPCC. Climate Change 2013: The Physical Science Basis. In Contribution of Working Group I to the fifth Assessment Report of the Intergovernmental Panel on Climate Change; Cambridge University Press: New York, NY, USA, 2013.

2. Owor, M.; Taylor, R.G.; Tindimugaya, C.; Mwesigwa, D. Rainfall intensity and groundwater recharge: Empirical evidence from the Upper Nile Basin. Environ. Res. Lett. 2009, 4, 035009. [CrossRef]

3. Şen, Z. Climate Change Expectations in the Upper Tigris River Basin, Turkey. Theor. Appl. Climatol. 2018, 1-17. [CrossRef]

4. Al-Ansari, N.A. Hydro Politics of the Tigris and Euphrates Basins. Engineering 2016, 8, 140-172. [CrossRef]

5. UN-ESCWA (United Nations Economic and Social Commission for Western Asia); BGR (BundesanstaltfürGeowissenschaften und Rohstoffe). Inventory of Shared Water Resources in Western Asia; Wishlist: Beirut, Lebanon, 2013; ISBN 978-1-53612-111-7.

6. Pauw, E.D.; Saba, M.; Sabah, H.A. Mapping Climate Change in Iraq and Jordan; ICARDA Working; International Center for Agricultural Research in Dry Areas (ICARDA): Beirut, Lebanon, 2015. [CrossRef]

7. Abbas, N.; Wasimi, S.A.; Al-Ansari, N. Impacts of Climate Change on Water Resources in Diyala River Basin, Iraq. J. Civ. Eng. Archit. 2016, 10, 1059-1074.

8. Adamo, N.; Al-Ansari, N.; Sissakian, V.K.; Knutsson, S.; Laue, J. Climate Change: Consequences on Iraq's Environment. J. Earth Sci. Geotech. Eng. 2018, 8, 43-58.

9. IssaI, E.; Al-Ansari, N.A.; Sherwany, G.; Knutsson, S. Expected Future of Water Resources within Tigris-Euphrates Rivers Basin, Iraq. J. Water Resour. Prot. 2014, 6, 421-432. [CrossRef]

10. Ezz-Aldeen, M.; Hassan, R.; Ali, A.; Al-Ansari, N.; Knutsson, S. Watershed Sediment and Its Effect on Storage Capacity: Case Study of Dokan Dam Reservoir. Water 2018, 10, 858. [CrossRef]

11. Al-Ansari1, N.; Issa, E.I.; Sherwani, G.; Knutsson, S. Sediment in the Mosul Reservoir of Northern Iraq. J. Environ. Hydrol. 2013, 21, 1-10.

12. Ankit, C.; Nitin, J.; Himanshu, P. Rainfall Runoff Analysis Using the Artificial Neural Network. Indian J. Sci. Technol. 2015, 8, 1-7.

13. Bakker, M.M.; Govers, G.; van Doorn, A.; Quetier, F.; Chouvardas, D.; Rounsevell, M. The response of soil erosion and sediment export to land-use change in four areas of Europe: The importance of landscape pattern. Geomorphology 2008, 98, 213-226. [CrossRef] 
14. Gassman, P.W.; Reyes, M.R.; Green, C.H.; Arnold, J.G. The soil and water assessment tool: Historical development, applications, and future research directions. Trans. ASABE 2007, 50, 1211-1250. [CrossRef]

15. Neitsch, S.L.; Arnold, J.G.; Kiniry, J.R.; Williams, J.R. Soil and Water Assessment Tool Theoretical Documentation Version 2009; Grassland, Soil and Water Research Laboratory, Agricultural Research Service and Blackland Research Center, Texas Agricultural Experiment Station: College Station, TX, USA, 2011.

16. Alwan, I.A.; Karim, I.R.; Mohamad, M.J. Modeling Water Harvesting System Using Soil Water Assessment Tool (Case study in Iraq). In Proceedings of the 2nd International Conference on Buildings, Construction and Environmental Engineering, Beirut, Lebanon, 17-18 October 2015.

17. Adeogun, A.G.; Sule, B.F.; Salami, A.W. Cost Effectiveness of Sediment Management Strategies for Mitigation of Sedimentation at Jebba Hydropower Reservoir, Nigeria. J. King Saud Univ. Eng. Sci. 2018, 30, 141-149. [CrossRef]

18. Leta, M.K.; Chakravarti, A. Sediment Yield Assessment and Mitigation Measures in Finchaa Watershed, Ethiopia. Int. J. Eng. Res. Technol. 2017, 6, 220-226.

19. Principe, J.A. Exploring Climate Change Effects on Watershed Sediment Yield and Land cover-based Mitigation Measures Using SWAT Model. In Proceedings of the 2012 XXII ISPRS Congress, Melbourne, Australia, 25 August-1 September 2012; Volume XXXIX-B8.

20. Li, T.; Gao, Y. Streamflow and Sediment Yield Variations in Response to Precipitation Changes: A Case Study of Xichuan Watershed in the Loess Plateau, China. Water 2015, 7, 5639. [CrossRef]

21. Zhou, Y.; Xu, Y.; Xiao, W.; Wang, J.; Huang, Y.; Yang, H. Climate Change Impacts on Flow and Suspended Sediment Yield in Headwaters of High-Latitude Regions-A Case Study in China's Far Northeast. Water 2017, 9, 966. [CrossRef]

22. Al-Khafaji, M.S.; Al-Mukhtar, M.M.; Mohena, A.S. Assessed the performance of SWAT Model for Long-Term Streamflow modeling within Al Adhaim Watershed, Iraq. Int. J. Sci. Eng. Res. 2017, 8, 1510.

23. Alwan, I.A.; Karim, I.R.; Mohamad, M.J. Sediment predictions in Wadi Al-Naft Using Soil Water Assessment Tool. In Proceedings of the 3rd International Conference on Buildings, Construction and Environmental Engineering, BCEE3, Sharm el-Shiekh, Egypt, 23-24 October 2017; Volume 162, p. 03008. [CrossRef]

24. Sehgal, V.; Sridhar, V. Watershed-scale Retrospective Drought Analysis and Seasonal Forecasting using Multi-layer, High-resolution Simulated Soil Moisture for Southeastern, U.S. Weather Clim. Extrem. 2018, 23, 100191. [CrossRef]

25. Al-Khafaji, M.S.; Saeed, F.H. Effect of DEM and Land Cover Resolutions on Simulated Streamflow of Adhaim Watershed by SWAT Model. Eng. Technol. J. 2018, 36, 439-448.

26. Abbas, N.; Wasimi, S.; Al-Ansari, N.; Nasrin Baby, S. Recent Trends and Long-Range Forecasts of Water Resources of Northeast Iraq and Climate Change Adaptation Measures. Water 2018, 10, 1562. [CrossRef]

27. Tomya, T.; Sumamb, K.S. Determining the Adequacy of CFSR Data for Rainfall-Streamflow Modeling Using SWAT. Procedia Technol. 2016, 24, 309-316. [CrossRef]

28. Moriasi, D.N.; Arnold, J.G.; Van Liew, M.W.; Bingner, R.L.; Harmel, R.D.; Veith, T.L. Model evaluation guidelines for systematic quantification of accuracy in watershed simulation. Am. Soc. Agric. Biol. Eng. 2007, 50, 885-900.

29. Fuka, D.R.; Walter, M.T.; MacAlister, C.; Degaetano, A.T.; Steenhuis, T.S.; Easton, Z.M. Using the Climate Forecast System Reanalysis as weather input data for watershed models. Hydrol. Process. 2013, 28, 5613-5623. [CrossRef]

30. Al-Faraj, F.A.; Scholz, M. Incorporation of the Flow Duration Curve Method within Digital Filtering Algorithms to Estimate the Base Flow Contribution to Total Streamflow. Water Resour. Manag. 2014, 28, 5477-5489. [CrossRef]

31. Khassaf, S.I.; Al-Adili, A.S.; Rasheed, R.S. Seepage Analysis Underneath Diyala Weir Foundation. In Proceedings of the Thirteen International Water Technology Conference, IWTC, Hurghada, Egypt, 12-15 March 2009.

32. Muchoney, D.; Borak, J.; Chi, H.; Friedl, M.; Gopal, S.; Hodges, J.; Morrow, N.; Strahler, A. Application of the MODIS global supervised classification model to vegetation and land cover mapping of Central America. Int. J. Remote Sens. 2000, 21, 1115-1138. [CrossRef]

33. Al-Ansari, N.; Al-Jabary, M. Hydrology and sedimentation of the Diyala River. Arabic. unpublished. 1988.

34. Maurer, E.P.; Brekke, L.; Pruitt, T.; Thrasher, B.; Long, J.; Duffy, P.B.; Dettinger, M.D.; Cayan, D.; Arnold, J. An enhanced archive facilitating climate impacts analysis, B. Am. Meteorol. Soc. 2014, in press. [CrossRef] 
35. NASH, J.E.; Sutcliffe, J.V. River Flow Forecasting Through Conceptual Models Part1. J. Hydrol. 1970, 10, 282-290. [CrossRef]

36. Abbaspour, K.C.; Rouholahnejad, E.; Vaghefi, S.; Srinivasan, R.; Yang, H.; Kløve, B. A continental-scale hydrology and water quality model for Europe:Calibration and uncertainty of a high-resolution large-scale SWAT model. J. Hydrol. 2015, 524, 733-752. [CrossRef]

37. SWAT-CUP User Manual. SWAT Calibration and Uncertainty Programs-A User Manual, Eawag Aquatic Research, Eawag Swiss Fedral Insatiate of Aquatic Sciences and Technology. 2015. Available online: https://swat.tamu.edu/media/114860/usermanual_swatcup.pdf (accessed on 6 June 2019).

(C) 2019 by the authors. Licensee MDPI, Basel, Switzerland. This article is an open access article distributed under the terms and conditions of the Creative Commons Attribution (CC BY) license (http://creativecommons.org/licenses/by/4.0/). 